BULLETIN Bulletin hispanique

HISPANIQUE Université Michel de Montaigne Bordeaux

119-2 | 2017

La Égloga renacentista en el Reino de Nápoles

\title{
El banquete de damas y caballeros
}

la corte galante de Carlos V en Nápoles

\section{Carlos José Hernando Sánchez}

\section{OpenEdition}

Journals

Édition électronique

URL : http://journals.openedition.org/bulletinhispanique/5020

DOI : 10.4000/bulletinhispanique.5020

ISSN : 1775-3821

Éditeur

Presses universitaires de Bordeaux

Édition imprimée

Date de publication : 1 décembre 2017

Pagination : 427-458

ISBN : 979-10-300-0218-8

ISSN : 0007-4640

Référence électronique

Carlos José Hernando Sánchez, «El banquete de damas y caballeros », Bulletin hispanique [En ligne], 119-2 | 2017, mis en ligne le 28 décembre 2020, consulté le 13 janvier 2021. URL : http://

journals.openedition.org/bulletinhispanique/5020 ; DOI : https://doi.org/10.4000/bulletinhispanique. 5020 


\title{
El banquete de damas y caballeros: la corte galante de Carlos V en Nápoles
}

\author{
Carlos José Hernando Sánchez \\ Universidad de Valladolid
}

L'Entrée triomphale de Charles Quint et de la cour impériale à Naples après la conquête de la Tunisie fit de la capitale parthénopéenne la scène privilégiée du déploiement de la rhétorique du pouvoir, comme le reflètent la correspondance diplomatique et un large répertoire de sources et de genres littéraires en particulier l'églogue, propre à exprimer les conflits à travers un langage idéalisé.

Mots-clés: Naples, Charles Quint, Pedro de Toledo, Garcilaso, Églogue politique.

La Entrada triunfal de Carlos V y la corte imperial en Nápoles tras la conquista de Túnez hizo de la capital partenopea un escenario privilegiado para el despliegue de la retórica del poder, como reflejan la correspondencia diplomática y un amplio repertorio de fuentes y géneros literarios entre los que destaca la égloga, idónea para expresar conflictos bajo un lenguaje idealizado.

Palabras clave: Nápoles, Carlos V, Pedro de Toledo, Garcilaso, Égloga política.

The triumphal entry of Charles $\mathrm{V}$ and the imperial court in Naples following the conquest of Tunis transformed the Parthenopean capital into a privileged setting for the display of the rhetoric of power, as seen in diplomatic correspondence and a broad repertoire of literary sources and genres especially the eclogue, adapted to express conflicts in an idealized language.

Keywords: Naples, Charles V, Pedro de Toledo, Garcilaso, political eclogue. 


\author{
De aquí iremos a ver de la Sirena \\ la patria, que bien muestra aver ya sido \\ de ocio y d'amor antiguamente llena \\ (Garcilaso de la Vega, Elegía II, a Boscán).
}

\section{DONNA DE'RE}

Desde Sicilia, Garcilaso transmitía a Boscán en su II elegía el anhelo por regresar a Nápoles, transfigurada en espacio galante. En la distancia campamental la nostalgia amorosa le llevaba a constatar la disparidad de inquietudes intelectuales y cortesanas en el ejército vencedor de Túnez. Tras evocar a Virgilio, el poeta remedaba la sátira I de Horacio para escribir a su amigo de Barcelona unos versos que siguen resonando con eco enigmático:

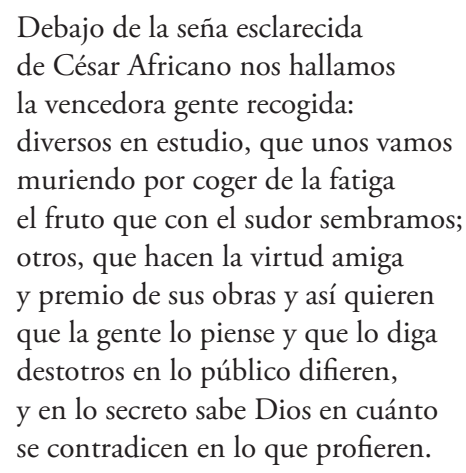

Las contradicciones latentes «en lo secreto» o afloradas «en lo público» -siempre opacas conforme al arte de la disimulación cortesana- encerraban también unas diferencias políticas que, a través de las tramas de la facción y la clientela, se pondrían de manifiesto durante la larga estancia napolitana. Como respuesta a esas diferencias los recursos multiplicados del lenguaje clasicista iban a verter diversos mensajes en los festejos organizados para celebrar la victoria y el reencuentro de la ciudad con el soberano. En «la patria de la sirena», la corte militar que protagonizó la campaña africana daría paso a la corte aristocrática, inmersa en la sociedad galante de una ciudad «abitata da principi», como más tarde la describiría Torquato Tasso ${ }^{1}$, hijo del culto Bernardo, unido para siempre con Luigi Tansillo y Antonio Minturno en el soneto que Garcilaso dedicó a María de Cardona, la "décima moradora del Parnaso», cuya boda en 1536 con Francesco de Este, hermano del duque de Ferrara, se celebró en Nápoles con unas pioneras representaciones teatrales a cargo de la compañía sienesa traída por su pariente el príncipe de Salerno ${ }^{2}$. El poeta castellano frecuentó los

1. Véase Torquato Tasso, «Il Porzio overo de le virtù», en id., Dialoghi, ed. E. Raimondi, Florencia, Sansoni Ed., 1958, vol. II, p. 995.

2. Véase Antonio Castaldo, Historia di Napoli, BNN, ms. XV-G-22, [publicado como 
círculos humanísticos patrocinados por la nobleza ${ }^{3}$ y siguió impregnándose de la tradición arcádica recreada por Pontano y Sannazaro a partir de Virgilio ${ }^{4}$, para aunar la historia amorosa de sus pastores con el panegírico del virrey de Nápoles, Pedro de Toledo, o con la más extensa narración épica que constituye el núcleo de su II égloga en elogio del sobrino de este, el joven Fernando Álvarez de Toledo, III duque de $\mathrm{Alba}^{5}$, convertido en 1535 por otro de sus amigos, Juan Ginés de Sepúlveda, en modelo de una nobleza consagrada al diálogo de las armas y las letras ${ }^{6}$.

No se trataría ya de la simple evocación heroica de la batalla legitimada por el acervo mesiánico de la tradición virgiliana, conocida por el Emperador desde 1533, cuando se encontró con Ariosto. Este le dedicó entonces una nueva versión de su Orlando Furioso con varias estrofas donde lo celebraba como otro Augusto, restaurador de la justicia encarnada por la mítica Astrea, junto a algunos de sus nobles capitanes distinguidos en las guerras de Italia. El César aparecía así fundido con la aristocracia guerrera, en un friso histórico destinado a ejercer gran influencia en la representación de las glorias de la Monarquía de España ${ }^{7}$. Ahora, apartadas «las armas y el furor de Marte», que Garcilaso había

Dell'historia, lib. IV, nei quali si descrivono gli avvenimenti più memorabili succeduti nel Regno di Napoli sotto il governo del Vicerè D. Pietro di Toledo, e dei Vicerè suoi successori fino al Card. Granvela, Nápoles, Raccolta Gravier, 1769], p. 98v. Cf. Edward Williamson, Bernardo Tasso, Roma, Edizioni di Storia e Letteratura, 1951; Emilio Sarli, La decima musa del Parnaso: Maria de Cardona, Tricase, Youcanprint, 2012 y José Manuel Pedrosa, «El Soneto XXIV de Garcilaso: mito de fundación, alegoría galante», Olivar, vol. 14, nº 19, diciembre 2013.

3. Véase Carlos José Hernando Sánchez, «Nobiltà e potere vicereale a Napoli nella prima metà del '500”, en Aurelio Musi (dir.), Nel sistema imperiale. L'Italia spagnola, Nápoles, Edizioni Scientifiche Italiane, 1994, pp. 147-163; id., «La cultura nobiliaria en el virreinato de Nápoles durante el siglo XVI", Historia Social, no 28, 1997, pp. 95-112.

4. Véase Carlos José Hernando Sánchez, «Parthénope ¿tan lejos de su tierra? Garcilaso de la Vega y la poesía de la corte en Nápoles», en José María Díez Borque y Luis Ribot García (eds.), Garcilaso y su época: del amor y la guerra, Madrid, Sociedad Estatal de Conmemoraciones Culturales, 2003, pp. 71-141; Eugenia Fosalba, «El exordio de la Epistola a Boscán: contexto napolitano», Studia Aurea, vol. 5, 2011, pp. 23-47; id., «Sobre la relación de Garcilaso con Antonio Tilesio y el círculo de los hermanos Seripando", Cuadernos de Filología Italiana, no 19 , 2012, pp. 131-144.

5. Véase Bienvenido Morros, «Albanio como don Fernando de Toledo en la II Égloga de Garcilaso", Analecta Malacitana, vol. XXXI, n 1, 2008, pp. 7-29, y Antonio Gargano, "Las extrañas virtudes y hazañas de los hombres”. Épica y panegírico en la Égloga Segunda de Garcilaso de la Vega", Criticón, no 115, La poesía épica en el Siglo de Oro, 2012, pp. 11-43.

6. Véase Juan Ginés de Sepúlveda, De convenientia militaris disciplinae cum christiana religione [...] qui inscribitur Democrates, Roma, Antonio Blado, 1535: traducción española en Diálogo llamado Demócrates, ed. Francisco Castilla Urbano, Madrid, Tecnos, 2012. Cf. Francisco Castilla Urbano, "Vida activa, virtud y gloria en la etapa italiana de Juan Ginés de Sepúlveda (15151536)", en Estudios filosóficos, vol. LVIII, no 169, 2009, pp. 421-455 y, de este mismo autor, El pensamiento de Juan Ginés de Sepúlveda. Vida activa, humanismo y guerra en el Renacimiento, Madrid, Centro de Estudios Políticos y Constitucionales, 2013.

7. Véase Francis Yates, Astrea. L'idea di Impero nel Cinquecento, Turín, Einaudi, 1990 (1 $1^{\text {a }}$ ed. en inglés, 1975), pp. 30-36. Cf. Guido Beltramini y Adolfo Tura (coords.), Orlando Furioso. 500 anni, Ferrara, Fondazione Ferrara Arte, 2016. 
evocado en su soneto a Boscán, era el tiempo de gozar los laureles de la victoria para hacer que «el romano imperio reverdesca». Por ello, la corte napolitana del Emperador se nutriría "de ocio y d'amor» también en su dimensión política, aunque celando bajo la armonía de los discursos oficiales las tensiones entre las élites. Hasta las más convencionales imágenes acabarían mostrando una realidad atormentada como el corazón del poeta, tampoco ajeno a esos conflictos en la difícil andadura clientelar que le llevó a intentar compatibilizar la amistad del virrey Toledo con la de su principal adversario, el marqués del Vasto Alfonso de Ávalos -también capitán y poeta- ${ }^{8}$, quizás el clarísimo marqués de uno de sus sonetos más cortesanos ${ }^{9}$. Ávalos y Toledo protagonizarían algunos de los más clamorosos conflictos galantes y ceremoniales en estancias palaciegas rodeadas por fachadas y estatuas de efímera grandeza.

Esposa de reyes, madre de ingenios, fuente de gloria..., en versos como los dedicados A Carlo QuintoImperadore, vincitordell'Africa porAntonio Minturno ${ }^{10}$, Nápoles se revestía con las habituales metáforas de amor y sometimiento para expresar la lealtad a su señor, colofón de una larga espera. La imagen conyugal de la esposa que aguarda a su marido remitía a la autoridad del soberano como pater familias, de acuerdo con la concepción aristotélica del poder codificada por la tratadística de oeconomica, unida a la idea del amor político que a partir de Cicerón y Petrarca formuló en 1490 Pontano en su tratado De obedientia como fidelitatis fundamentum, según el deber mutuo de lealtad entre la sociedad y el príncipe -frente a la posterior exaltación maquiaveliana del temor-, sellado

8. Véase Carlos José Hernando Sánchez, «Una visita a Castel Sant’Elmo: famiglie, città e fortezze a Napoli tra Carlo V e Filippo II", Annali di Storia Moderna e Contemporanea, anno VI, no 6, 2000, pp. 39-89; Tobia Toscano, «Due allievi di Vittoria Colonna: Luigi Tansillo e Alfonso d'Avalos», Critica letteraria, no 16, 1988, pp. 739-773; id., "Tra corti e campi di battaglia: Alfonso d'Avalos, Luigi Tansillo e le affinità elettive tra petrarchisti napoletani e spagnoli», e-Spania. Revue interdisciplinaire d'études hispaniques médiévales et modernes, no 13 , junio 2012, y Antonio Gargano, Con canto acordado. Estudios sobre la poesía entre España e Italia en los siglos XV-XVII, Sevilla, Universidad de Sevilla, 2012, pp. 259-274.

9. Véase Daniel L. Heiple, Garcilaso de la Vega and the Italian Renaissance, University ParkPA, The Pennsilvanya State University Press, 1994, pp. 267 y ss, y Antonio Gargano, Con canto acordado..., pp. 267-269, favorables a la identificación con el marqués del Vasto.

10. «Bella, famosa, e chiara / Di Partenope pria, di Febo poi / Città, che al grande Alcide / Fosti un tempo sì cara, / Chén te lasciò de' bei vestigi suoi, / Ond'ancor lieta ride / La piaggia tua, che vide / I pellegrini armenti, / Donna de 'Re d'ogni alto imperio degni, / Madre d'illustri ingegni, I D'animi sempre al sommo onore intenti, / Viva e perpetua fonte / Di prove al mondo gloriose, e conte, / Come lieta sarai, / Quando il tuo Re vedrai? [...] Come ne vien la pace / Dopo la guerra, al bel trionfo segua / La festa in lieta gioia, / Raccenda Amor la face, / Et habbia il fin, che più si brama, ò tregua / Ogni gravosa noia, / L'odio, e lo sdegno muoia, / E la concordia viva, / Viva l'umana, e la divina legge, / Ondél mondo si regge, / E con la palma la tranquilla oliva. / Riprendi i panni allegri, / Lasciando à parte i pensier gravi, et egri, / Mostra l'alto valore / Napoli al tuo Signore [...] Che eternamente sacra, I E del suo nome sia / La bella festa in te per ogni via...", Rime et Prose del Sig. Antonio Minturno, nuovamente andate in luce allillustrissimo sig. don Girolamo Pignatello, Venecia, Francesco Rampazzetto, 1559, pp. 179-182. Cf. Raffaele Calderisi, Antonio Sebastiano Minturno. Poeta e trattatista del cinquecento dimenticato, Aversa, Tip. Fratelli Noviello, 1921. 
por un pacto social, jurídico y simbólico ${ }^{11}$. Esa imagen se plasmaría tanto en la entrada del monarca como en la sucesión de festejos que jalonaron la estancia en una ciudad que adornaba calles, jardines y palacios como un gigantesco lecho nupcial. La regia esposa desplegaba un rito de seducción a través de la imagen galante, complementaria de la conyugal, que erigía el cuerpo global de la república en objeto del deseo imperial proyectado sobre sus miembros individuales y colectivos, desde la familia aristocrática, representada por los grandes linajes con diversas lealtades faccionales, hasta un reino oscurecido por el protagonismo de la ciudad, cuerpo lacerado por múltiples contradicciones entre los cinco seggi, que competían por monopolizar los privilegios del patriciado, cada vez más celoso de un poder identificado con su reputación, frente al popolo-los estratos medios y adinerados que desde 1495 contaban con su propio seggio-, favorecido primero por los reyes aragoneses locales, luego por los sucesivos virreyes. Esposa y amante, Nápoles -sus múltiples cuerpos y rostros- se convertía también en la hija «che senza padre è stata cotanti anni», según otro poeta que tendría una participación destacada en la visita imperial, el secretario del reino Bernardino Martirano, cuyo Pianto d'Aretusa constituye uno de los principales espejos literarios de la experiencia social y política de aquella visita, desde la estancia del Emperador, antes de su entrada oficial, en la villa de Leucopetra, hasta la exaltación heroica de los nobles napolitanos participantes en la campaña de Túnez, siguiendo la estela ariostesca ${ }^{12}$.

Tras los primeros días en Trápani, donde seguramente Garcilaso escribió su elegía a Boscán, el apresurado recorrido por el norte de Sicilia culminó con la entrada en Mesina ${ }^{13}$, escenificación del triunfo del poder tras la crisis que había dividido a la sociedad política de la isla a raíz de la oleada de revueltas y conspiraciones nobiliarias estalladas entre 1516 y 1523. La muerte del virrey napolitano de Sicilia Ettore Pignatelli, duque de Monteleone -cuyas inquietudes literarias, plasmadas en la estrecha relación con Antonio Minturno, que bajo su gobierno compuso probablemente L'Amore innamorato, editado en Venecia en 1559, reflejan las tensiones espirituales y políticas- ${ }^{14}$, dio paso al nombramiento como nuevo pro rege de Ferrante Gonzaga, hermano del duque de Mantua y príncipe de Molfetta por su matrimonio en 1529 con Isabella di Capua, una de las principales feudatarias del Reino de Nápoles ${ }^{15}$.

11. Véase Daniela Frigo, Il padre di famiglia: governo della casa e governo civile nella tradizione dell"economica' tra Cinque e Seicento, Roma, Bulzoni, 1985 y Guido M. Cappelli, «Machiavelli, l'umanesimo e l'amore politico", Engramma [revista online], no 134, marzo 2016.

12. Bernardino Martirano, Il pianto d'Aretusa, ed. Tobia R. Toscano, Nápoles, Loffredo, 1993, pp. 92-93, estrofas 139-140.

13. Véase M. Capraro, «21 ottobre 1535: l'ingresso di Carlo V a Messina», Lexicon, no 5-6, 2007-2008, pp. 95-102; J. M. Morales Folguera, «El viaje triunfal de Carlos V por Sicilia tras la victoria de Túnez», IMAGO. Revista de emblemática y cultura visual, no 7, 2015, pp. 97-111.

14. Véase B. Grazioli, «L'Amore innamorato’ di Antonio Minturno», en Il prossimetro nella letteratura italiana, ed. Andrea Comboni y Alessandra di Ricco, Trento, Università degli studi di Trento, 2000, pp. 351-406 y Carmen Salvo, La biblioteca del vicerè. Politica, religione e cultura nella Sicilia del Cinquecento, Roma, Il Cigno Ed., 2004.

15. Véase Luigi Pescasio, Don Ferrante Gonzaga, Principe di Molfetta, Signore di Guastalla, 
La entrada de Messina, organizada por artistas como Polidoro da Caravaggio y humanistas como Francesco Maurolico, resultó crucial en la consagración de la imagen imperial de inspiración virgiliana que iba a desplegarse en el conjunto del itinerario triunfal por Italia ${ }^{16}$. Con esos precedentes, las más diversas tensiones políticas condicionaron la prolongada estancia napolitana de Carlos V en el invierno de 1535-36, como ya había sucedido con su propia entrada en la ciudad, diseñada, según la tradición historiográfica, por el arquitecto Ferdinando Manlio, los escultores Giovanni da Nola y Girolamo Santacroce y los pintores Andrea da Salerno y Giovanni Antonio d'Amato «il vecchio», que habrían dado forma al programa iconográfico de Marco Antonio Epicuro y de un joven Bernardino Rota - próximos al marqués del Vasto-, autores de las inscripciones latinas inspiradas en Virgilio y, en ocasiones, en Sannazaro ${ }^{17}$. Durante esos meses Nápoles se convirtió en el principal escenario de la reputación para los nobles españoles e italianos ${ }^{18}$, sobre el trasfondo de las guerras con Francia, que después de la Paz de las Damas firmada en Cambrai en 1529 se reiniciaron con la nueva ofensiva de Francisco I tras la incorporación de Milán al patrimonio del Emperador a la muerte del duque Francesco Sforza. La tensión bélica, latente durante toda la estancia, siguió condicionando las estructuras políticas y militares en los estados italianos y en las grandes monarquías contendientes ${ }^{19}$, así como los códigos aristocráticos

Vicerè di Sicilia, Governatore di Milano, Stratega dell'Imperatore Carlo V, Suzzara, Ed. Bottazzi, 2000; Caterina De Gioia Gadaleta, Isabella di Capua Gonzaga, Principessa di Molfetta, signora di Guastalla, Molfetta, Biblioteca Maldotti, 2003 y, sobre todo, Gianvittorio Signorotto, Ferrante Gonzaga. Il Mediterraneo, l'Impero (1507-1557), Roma, Bulzoni, 2009.

16. Véase José Miguel Morales Folguera, "Las entradas triunfales de Carlos V en Italia», en Diálogos de Arte. Homenaje al profesor Domingo Sánchez-Mesa Martín, Granada, Universidad de Granada, 2014, pp. 327-342.

17. Véase Maria Luisa Madonna, «El viaje de Carlos V por Italia después de Túnez: el triunfo clásico y el plan de reconstrucción de las ciudades», en Alfredo Morales (coord.), La fiesta en la Europa de Carlos V, Madrid, Sociedad Estatal para la conmemoración de los centenarios de Felipe II y Carlos V, 2000, pp. 119-153; Maria Antonietta Visceglia, «Il viaggio cerimoniale di Carlo V dopo Tunisi», en José Martínez Millán (coord.), Carlos Vy la quiebra del humanismo político en Europa (1530-1558), Madrid, Sociedad Estatal para la Conmemoración de los Centenarios de Felipe II y Carlos V, 2001, vol. II, pp. 133-172; Carlos José Hernando Sánchez, «El Glorioso Trivmpho de Carlos V en Nápoles y el humanismo de corte entre Italia y España», en G. Galasso (coord.), Carlo V, Napoli e il Mediterraneo, Napoli, Società Napoletana di Storia Patria, 2001, pp. 447-521 y Tobia R. Toscano, "Le Muse e i Colossi: apogeo e tramonto dell'umanesimo politico napoletano nel 'trionfo' di Carlo V (1535) in una descrizione a stampa», Critica letteraria, no 115-116, 2002, pp. 377-410.

18. Véase Marcello Fantoni (coord.), Carlo Ve l'Italia, Roma, Bulzoni, 2000; Bruno Anatra y Francesco Manconi (coords.), Sardegna, Spagna e Stati italiani nell'età di Carlo V, Urbino, Carocci, 2001; Francesca Cantù y Maria Antonietta Visceglia (coords.), L'Italia di Carlo V. Guerra, religione e politica nel primo Cinquecento, Roma, Viella, 2003; E. Bonora, Aspettando l'Imperatore. Principi italiani tra il papa e Carlo V, Turín, Einaudi, 2014.

19. Véase Jean-Claude Zancarini y Jean-Louis Fournel, Les guerres d'Italie. Des batailles pour l'Europe (1494-1559), París, Gallimard, 2003, y Michael Mallett y Christine Shaw, The Italian Wars 1494-1559: War, State and Society in Early Modern Europe, Londres, Pearson, 2012. 
de la tradición caballeresca ${ }^{20}$ y el conjunto de los criterios de representación del poder, impregnados por el lenguaje clasicista ${ }^{21}$. Ese es el marco vital de Garcilaso y de la retórica humanística -incluido el petrarquismo políticoque, junto al renovado arte de la guerra ${ }^{22}$, envolvía pugnas de familia como las fundadas en lealtades güelfas y gibelinas, transmitidas en Nápoles por las facciones angevina y aragonesa, que siguieron encauzando la práctica del poder con una acendrada carga simbólica ${ }^{23}$.

Todos esos factores se reflejaron en la auto celebración de la ciudad, asociada al César del que esperaba recibir nuevas gracias para sus élites. El virrey Pedro de Toledo, tras cumplirse el primer trienio de su mandato y ver contestada su dureza frente a la poderosa nobleza feudal, preparó el entramado viario para recibir a su señor con la belleza digna de un César. Por ello, Girolamo Borgia, en su poema latino sobre la victoria africana, exaltaría la transformación de la imagen urbana con motivo de la visita imperial ${ }^{24}$, preludio de la gran reforma que iba a realizarse en los años siguientes ${ }^{25}$. Por eso también se discutió seriamente sobre la forma del ingreso imperial. En su poema Minturno auspiciaba: "Vedrail tuo Re, che à gloria / Rara, si trionfal carro conduce, / Qual non vide altra etate». La imagen del carro, inmortalizada en el arco de acceso a la residencia regia de Castel Nuovo tras la recuperación de la ceremonia romana del adventus o triunfo por Alfonso V de Aragón en su entrada de 1443, estaba tan difundida -por obra, entre otros, de autores como Pontano en su tratado De Magnificentia - que Garcilaso recurriría a ella en su II égloga para exaltar al III duque de Alba tras su participación en el socorro imperial a Viena frente a los turcos en 1532:

20. Véase Nicolas Le Roux, Le crépuscule de la chevalerie. Noblesse et guerre au siècle de la Renaissances, Ceyzérieu, Champ Vallon, 2015.

21. Véase Danielle Boillet y Marie-Françoise Piéjus (eds.), Les guerres d'Italie. Histoire, pratiques, représentations (Actes du Coloque international, Paris, 9-11 décembre 1999), París, Centre interuniversitaire de recherche sur la Renaissance italienne, 2002.

22. Véase Mario Santoro, Tristano Caracciolo e la cultura napoletana della Rinascenza, Nápoles, Armanni, 1957, pp. 133-156; Guido M. Cappelli, «Petrarca e l'umanesimo politico del Quattrocento", Verbum. Analecta Neolatina, t. VII, no 1, 2005, pp. 153-175 y Carlos José Hernando Sánchez, «La defensa de un reino: imagen y práctica de la guerra en la cultura napolitana del Renacimiento», en Francisco Galante Gómez (dir.), Caminos legendarios. Los Tercios y el Regimiento Soria en la Historia y la Cultura, Madrid, Ed. Rueda, 2009, pp. 59-82.

23. Véase Marco Gentile (ed.), Guelfi e ghibellini nell'Italia del Rinascimento, Roma, Viella, 2005.

24. «Salve Parthenope facta potentior / Augente imperium Caesare Romuli, / Gaude Parthenope facta beatior / Servanti populis iustitia tuos: / Ride Parthenope facta venustior: / silices saxaque; lubrica / Posthac haud metues ulla pericula. / En argilla vias nunc tibi conctilis / Stravit per faciles. hoc tibi commodi / Hoc deerat decoris: nunc age Praesidem / Auctorem decoris tolle simillimum / Traiano meritis laudibus aethera / Ad summum...", Girolamo Borgia, Africana Caesaris Victoria, Nápoles, 1535, pp. 16-16v.; cf. id., Carmina Lyrica et Heroica, Venecia, Ex Typographia Iacobi Zattoni, 1666, pp. 136-139, 268 y 299.

25. Carlos José Hernando Sánchez, «Corte y ciudad en Nápoles durante el siglo XVI. La construcción de una capital virreinal», en Francesca Cantù (ed.), Las Cortes virreinales de la Monarquía Española: América e Italia, Roma, Viella, 2008, pp. 337-423. 
Estaba figurado un carro estraño con el despojo y daño de la gente bárbara, y juntamente allí pintados cautivos amarrados a las ruedas, con hábitos y sedas variadas; lanzas rotas, celadas y banderas, armaduras ligeras de los brazos, escudos en pedazos divididos, vieras allí cogidos en trofeo, con que el común deseo y voluntades de tierras y ciudades se alegraba.

Para alegrar ese «común deseo», más allá del abigarrado cúmulo de trofeos militares, las autoridades municipales de Nápoles, de acuerdo con la corte imperial, optaron por la entrada a caballo, según la ceremonia antigua de la ovatio -seguida en Nápoles por Carlos VIII de Francia en 1495 y por Fernando el Católico en 1506-, frente a la progressio del aparatoso carro empleado por Alfonso V. Si este podía remitir a la renovatio imperii que, de acuerdo con la tradición gibelina, pretendía enlazar directamente con el mito augusteo -y por tanto virgiliano-, aquella, más modesta en apariencia y próxima a la exhibición caballeresca, evocaba la pausada legitimidad de la translatio imperii desde la continuidad heredada de Carlomagno -consagrada en las coronaciones de Aquisgrán y Bolonia- que iba a ratificarse en la próxima entrada romana con la bendición del papa Paulo III Farnese, a pesar de la retórica heroica de un ritorno all'Antichità plasmado en imágenes y poemas ${ }^{26}$, decisivos en la consolidación del discurso imperial durante el resto del reinado ${ }^{27}$. En 1530 la ceremonia de Bolonia envolvió bajo la aparente nostalgia del Sacro Imperio un acto político en el que cristalizaban las tratativas con el pontífice y los potentados italianos. Los nobles y magnates presentes en Bolonia gozaron del favor, el honor y la gracia de los que dependía la conservación y el aumento de sus privilegios. Así lo reflejarían los humanistas y artistas llamados a erigir el tema de la paz, más allá de los objetivos de una u otra facción cortesana, en el eje de un nuevo

26. Véase Bonner Mitchell, «Carlos V como triunfador», en Pedro Navascúes Palacio (ed.), Carolvs V Imperator, Madrid, Lunwerg, 1999, pp. 213-251; Marcello Fantoni, «Carlo V e l'immagine dell"imperator", en Marcello Fantoni (coord.), Carlo Ve l'Italia, op. cit., pp. 101-114 y Peter Burke, «Limage de Charles Quint. Construction et interprétation», en Wim Blockmans, Peter Burke, Fernando Checa Cremades, Geofrey Parker, et alii (eds.), Charles Quint 15001558. L'Empereur et son temps, París, Actes-Sud, 2000, pp. 393-475. Cf. Antonietta Iacono, "Il trionfo di Alfonso d'Aragona tra memoria classica e propaganda di corte», Rassegna storica salernitana, no 51, 2009, pp. 9-57 y Fulvio delle Donne, "Il trionfo, l'incoronazione mancata, la celebrazione letteraria: i paradigmi della propaganda di Alfonso il Magnanimo", Archivio Storico Italiano, anno CLXIX, 2011, pp. 447-476.

27. Véase José Luis Gonzalo Sánchez-Molero, «El humanismo áulico carolino: discursos y evolución», en José Martínez Millán (coord.), Carlos Vy la quiebra del humanismo político en Europa (1530-1558), op. cit., vol. III, pp. 125-152. Cf. Françoise Crémoux y Jean-Louis Fournel (eds.), Idées d'empire en Italie et en Espagne (XIV $\mathrm{e}-X V I I^{\mathrm{e}}$ siècle), Mont-Saint-Aignan, Publications des Universités de Rouen et du Havre, 2010. 
consenso. Si la antigua ciudad universitaria era un marco adecuado para exponer la imagen renovada del Emperador como dominus mundi, defendida por su prestigiosa escuela de derecho romano, el ceremonial actuaría como instrumento legitimador a través de la reconstrucción -diríase filológica, conforme a los studia humanitatis-, de un ritual caído en desuso como era la coronación con la corona de hierro longobarda, transportada desde Monza y realizada de forma casi privada en la capilla palaciega el 22 de febrero de 1530, dos días antes de la solemne coronación imperial en la basílica de San Petronio. Su sentido político estaba ligado tanto a la restauración del duque Francesco II Sforza en Milán como a la reafirmación de los derechos imperiales sobre el Norte de Italia ${ }^{28}$.

Más complejas parecen las lecturas de las ceremonias de 1535, en función de la necesidad de disimular las tensiones de la sociedad napolitana. A la batalla simbólica del carro le siguió la pugna ceremonial por las varas del palio entre varios nobles locales ${ }^{29}$. Consumado el recibimiento, los festejos que se sucedieron iban a escenificar el juego galante entre el Emperador y el reino. El arte de cortejar, fundido con la ceremonialidad cortesana en plena ebullición, siguió encerrando una enconada batalla política. Los principales barones del reino, encabezados por el marqués del Vasto - general de la infantería durante la pasada campaña africana-, el príncipe de Salerno Ferrante Sanseverino y el príncipe de Melfi Andrea Doria -almirante de la flota que había hecho posible la conquista de la nueva Cartago-, propusieron infructuosamente la sustitución del virrey Toledo, tras las desavenencias agravadas durante la propia campaña de Túnez en la que participaron otros muchos nobles napolitanos. El escenario institucional de esa pugna fue el parlamento del reino, inaugurado por el soberano en enero de $1536^{30}$. Finalmente, el monarca mantendría su apoyo a don Pedro. La visita imperial se tradujo en un nuevo impulso a la reforma administrativa y judicial, que tendría su mejor expresión en las Gracias y Capítulos aprobados en la asamblea, en la prórroga del mandato del virrey -aunque genéricamente acotado por las nuevas instrucciones del soberano-y en

28. Véase Tiziana Bernardi, «Analisi di una cerimonia publica. L'incoronazione di Carlo V a Bologna», Quaderni storici, vol. 61, 1986, pp. 171-199; Gonzalo Máximo Borras Gualis y Jesús Fermín Criado Mainar (coords.), La imagen triunfal del Emperador: la jornada de la coronación imperial de Carlos $V$ en Bolonia y el friso del Ayuntamiento de Tarazona, Madrid, Sociedad Estatal para la conmemoración de los centenarios de Felipe II y Carlos V, 2000; Franz Bosbach, "Concepción imperial e imagen pública de Carlos V en su coronación en Bolonia», en A. Kohler (coord.), Carlos V/Karl V. 1500-2000, Madrid, Sociedad Estatal para la conmemoración de los centenarios de Felipe II y Carlos V, 2000, pp. 359-375, y Giovanni Sassu, Il ferro e l'oro. Carlo V a Bologna, Bolonia, Editrice Compositori, 2007.

29. Véase Carlos José Hernando Sánchez, «El Glorioso Trivmpho de Carlos V en Nápoles...», op. cit., pp. 505-521.

30. Véase Carlos José Hernando Sánchez, «El Parlamento del reino de Nápoles bajo Carlos V: formas de representación, facciones aristocráticas y poder virreinal», en Laura Casella (ed.), Rappresentanze e territori. Parlamento friulano e istituzioni rappresentative territoriali nell'Europa moderna, Udine, Forum, 2003, pp. 329-385. 
la consiguiente recopilación legislativa, a lo que se unió el anuncio de la primera visita de inspección a los oficios administrativos del reino, encomendada al obispo Pedro Pacheco, miembro de un linaje contrario a los Toledo en Castilla y por ello garantía de rigor en el examen del gobierno virreinal. Con todo, esas medidas no atenuaron la resistencia de los adversarios del virrey que acentuaría durante los años siguientes la división entre los grupos dirigentes ${ }^{31}$, mientras se reforzaba el ceremonial y la estructura de una corte virreinal investida con los atributos de un auténtico poder real en ausencia ${ }^{32}$.

\section{LA PIU PRINCIPALE BELLA ET FELICE CORTE CHE FUSSE STATA VISTA MAI IN ITALIA}

En 1561 la estancia de Carlos V era aún recordada por el regente de la Cancillería Geronimo Albertino -uno de los principales colaboradores de don Pedro de Toledo- en un memorial dirigido al virrey Pedro Afán de Ribera, I duque de Alcalá, para convencerlo de la necesidad de seguir permitiendo el crecimiento de la capital, con el argumento de que esta era capaz de sustentar a una población aún mayor de la que albergaba:

Come si n'e vista l'esperienze nell'anno 1535 et 1536 alla venuta del Imperatore Carlo Quinto dalla espeditione de Tunesi con infiniti numeri de signori cauallieri officiali et ministri di suoi Corti oue concorsero li legati et altri Cardenali et prelati con tanti signori de Italia et fuora con tutto il Baronaggio del Regno che dopo la giornata della Coronatione in Bologna questa fu la piu principale bella et felice corte che fusse stata vista mai in Italia.

Aún a principios del reinado de Felipe II se lamentaba la ausencia del soberano, más clamorosa puesto que la capital del reino «sotto la felicità dei tempi del Imperador Carlo Quinto e cresciuta assai più che sotto niun altro passato Prenciper, ${ }^{33}$. Las élites napolitanas seguían añorando la presencia de la corte que habían gozado por última vez en 1535 . En su núcleo se hallaba el séquito que había participado en la empresa africana, encabezado por algunos de los principales nobles de Castilla, Aragón y, también, de Portugal, cuyo infante don Luis,

31. Véase Carlos José Hernando Sánchez, Castilla y Nápoles en el siglo XVI: el virrey Pedro de Toledo. Linaje, Estado y cultura (1532-1553), Salamanca, Junta de Castilla y León, 1994 e $i d$., "Pedro de Toledo entre el hierro y el oro: construcción y fin de un virrey», en Encarnación Sánchez García (ed.), Rinascimento meridionale. Napoli e il viceré Pedro de Toledo (1532-1553), Nápoles, Tullio Pironti editore, 2016, pp. 3-65.

32. Véase Carlos José Hernando Sánchez, «Idea y realidad de una corte periférica en el Renacimiento. Aproximación a la dialéctica público-privado del poder virreinal en Nápoles durante la primera mitad del siglo XVI», en León Carlos Álvarez Santaló y Carmen Cremades Griñán (eds.), Mentalidad e ideología en el Antiguo Régimen. II Reunión Cientifica de la Asociación Española de Historia Moderna, 1992, Murcia, Universidad de Murcia, 1993, t. II, pp. 261-277.

33. "Relatione fatta per lo Signore Regente Albertino al Sr. Vice Re del Regno circa la Provisione da farsi che la citta di Napoli non hauesse a moltiplicare più de habitatori», BNN, ms. IX.C.20, ff. $97 \mathrm{v} .99$. 
hermano de la emperatriz Isabel y conocido por sus inquietudes literarias que le llevaron a proteger a Gil Vicente, acudió con un fuerte contingente naval ${ }^{34}$. El 25 de febrero de 1535, cuando la corte se disponía a dirigirse a Barcelona para preparar la campaña, Estefanía de Requessens, esposa del cortesano Luis de Zúniga, escribía desde Madrid a su madre la condesa de Palamós que « $S a$ Majestat crec irà millor acompanyat que l'altra volta [en referencia al último viaje imperial en 1533]; perquè van los que anaren llavors $i$ molts altres homes de titol" y citaba entre estos al duque de Alba, el conde de Benavente, los marqueses de Elche y Lombay y los condes de Valencia de Don Juan y Viana de Alentejo, entre otros ${ }^{35}$.

La visita imperial convirtió la capital del reino durante unos meses en un centro de la diplomacia italiana y europea. Al igual que en la retratística renovada por los modelos flamencos y venecianos dominantes en la corte imperial, nobles españoles, italianos, flamencos y alemanes exhibieron actitudes y atributos acordes con las exigencias del decoro incluso en las más desinhibidas celebraciones privadas como las mascaradas durante el carnaval ${ }^{36}$. El 23 de enero de 1536 el conde Niccolo Maffei informaría a su señor, el duque de Mantua Federico II Gonzaga, que «questa Citta per la grandezza che se ui uede é cosa incredibile, per esser piena de tanti Principi Duchi Marchesi Baroni et Gentilhuomini et poi tante belle Signore et Gentildonne chel numero seria sufficiente a fare un mondo da se> ${ }^{37}$. Las fiestas, que describe con profusión de detalles el mismo embajador de los Gonzaga -empeńados en la polémica sucesión del marquesado de Monferrato, cuya investidura debía solicitar el

34. Véase I. Mendes Drumond Braga, Um espaço, duas monarquias. Interrelaçoes na península Ibérica no tempo de Carlos V, Lisboa, Hugin, 2001.

35. Véase Max Cahner (ed.), Epistolari del Renaixement, Valencia, Albatros, 1978, vol. 2, p. 52. El 17 de marzo la misma Estefanía volvió a escribir a su madre desde Madrid: «Sa Majestat se té per cert que passarà en Africa i d'allí se creu a Nàpols [...] D'aci van tants grans senyors $i$ cavallers que seran molts més que l'altra volta...", ibidem, p. 65. Una relación de los principales nobles que formaron parte de la expedición, la mayor parte de los cuales siguió después hasta Nápoles, se encuentra en Francisco López de Gómara, Guerras de mar del Emperador Carlos V, ed. Miguel Ángel de Bunes y Edith Jiménez, Madrid, Sociedad Estatal para la conmemoración de los centenarios de Felipe II y Carlos V, 2000, p. 151.

36. Sobre la afición del Emperador a asistir enmascarado a cenas y bailes en los palacios napolitanos, incluso infringiendo el luto por la muerte de su tía la reina de Inglaterra Catalina de Aragón, informa el nuncio papal Fabio Arcella. Véase Paquale Villani, «Origine e carattere della nunziatura di Napoli (1523-1569)», Annuario dell'Istituto Storico Italiano per l'Età Moderna e Contemporanea, vol. IX-X, 1957-1958, pp. 370-373. Sobre el decoro, definido tempranamente en ámbito napolitano por Torres Naharro y Juan de Valdés, véase Palma Martínez-Burgos García, "El decoro. La invención de un concepto y su proyección artística», Revista de la Facultad de Geografía e Historia, no 2, 1988, pp. 91-102; Maxime Chevalier, "Decoro y decoros», Revista de Filología Española, t. LXXIII, fasc. 10-2º, enero-junio 1993, pp. 5-24 y David Mañero Lozano, "Del concepto de decoro a la "teoría de los estilos": consideraciones sobre la formación de un tópico clásico y su pervivencia en la literatura española del Siglo de Oro», Bulletin Hispanique, vol. 111, no 2, dicembre 2009, pp. 357-385.

37. ASMa., Archivio Gonzaga, busta 812, f. 107 bis. 
legado al Emperador- $-^{38}$, constituyen un testimonio excepcional del despliegue de medios suntuarios protagonizado por la aristocracia napolitana para agasajar al soberano e impresionar a su corte que, a la altura de 1535, había adquirido ya su plena configuración como crisol de los intereses, las inquietudes y los gustos predominantes en los distintos territorios del César ${ }^{39}$. Junto a una multitud de agentes diplomáticos atraídos por la presencia del César, algunos príncipes soberanos de la península, como los duques de Urbino, Ferrara y Florencia, se desplazaron hasta Nápoles con suntuosos cortejos cuyas necesidades de alojamiento, manutención y protocolo fueron atendidas por los nobles napolitanos. El duque de Urbino, por ejemplo, se alojó en el palacio de Ferrante Gonzaga, príncipe de Molfetta y nuevo virrey de Sicilia ${ }^{40}$, tras hacer su entrada en la ciudad de noche para evitar un embarazoso problema de protocolo a los nobles locales que habrían debido acudir a recibirlo, pero ese mismo gesto le hizo merecedor de nuevas muestras de consideración que aumentaron su reputación ante la corte ${ }^{41}$.

El Emperador ejerció su prescriptiva liberalidad repartiendo todo tipo de gracias y mercedes entre los legados y embajadores que habían acudido a agasajarlo, como a los cuatro enviados extraordinarios de la República de Venecia, recompensados con el título de caballeros ${ }^{42}$. Contamos con información detallada del viaje de esos diplomáticos, ya que a partir del 26 de noviembre de 1535, antes y después de entrar en el Reino de Nápoles por Abruzzo, su correspondencia insiste en el mal estado de los caminos. En Aversa se unen a la comitiva del duque de Ferrara, que también iba a Nápoles. En la capital partenopea son recibidos y agasajados por los consejeros y oficiales del Emperador. Pero se quejan del pésimo alojamiento, «essendo talmente piena la città per la corte grossa che tutti convengono star al meglio che possono", según

38. Sobre la legación de Maffei, véase Giuseppe Coniglio, «Note sulla società napoletana ai tempi di Don Pietro di Toledo", en Studi in onore di Riccardo Filangieri, Nápoles, Larte tipografica, 1959, vol. 2, pp. 345-365; Guido Rebecchini, «Per una biografia di Nicola Maffei», Civiltà mantovana, no XXXI, 1996, pp. 75-92 y Diane Bodart, Tiziano e Federico II Gonzaga. Storia di un rapporto di committenza, Roma, Bulzoni, 1998, pp. 137-141.

39. Véase José Martínez Millán (ed.), La corte de Carlos V, Madrid, Sociedad Estatal para la conmemoración de los centenarios de Felipe II y Carlos V, 2000, vol. I.

40. El 2 de enero el conde Niccolo Maffei, informaba desde Nápoles «como Il Sr. Duca d'Urbino sij gionto qua...» y que «s. exa serà accommodata della mità del Pallazzo dell'Illmo. Sor. Vicere di Sicilia, che de tutto non puó esser accomodata per la venuta del pto. sigr. qual d'hora si aspetta...", en tanto que el duque de Ferrara había emprendido ya el regreso a su ciudad y se encaminaba hacia Roma: ASMa., Archivio Gonzaga, busta 812.

41. "...hieri l'altro di sera Il Sr. duca d'Urbino gionse qui in Napoli, et per non incommodare questi Signori che sarebbono andati ad incontrarlo all'improuiso s'en tiene a due o tre hore di notte. Hier sera poi S. Exca stette molto a longo con S.Mt. dalla qualle e stata ben uista et accarezata et honorata da tucti questi Principi et signori», Niccolo Maffei al duque de Mantua, Nápoles, 9 de febrero de 1536, ASMa., Archivio Gonzaga, busta 812, f. 175.

42. El 7 de enero de 1536 Niccolo Maffei informaba al duque de Mantua desde Nápoles que «sua Mt. domattina uol creare Caualleri questi quattro Ambassri. venetiani che sono uenuti ad allegrarsi con s.Mt. et donargli una cathena d'oro de mille scuti per cada uno d'essi...", ASMa., Archivio Gonzaga, busta 812, f. 30. 
dicen al día siguiente de su llegada. Son recibidos en audiencia por el monarca en Castel Nuovo: los embajadores se dirigen a él en italiano y el César responde en castellano. Visitan a diversos cardenales presentes en Nápoles, así como a Cobos y Granvela, los poderosos secretarios imperiales, además de al virrey, un dato revelador de la confianza en su continuidad en el cargo frente a la oposición aristocrática. El príncipe de Salerno, uno de los cabecillas de esta, los invita a una velada en su casa, a la que acude el Emperador enmascarado, ocasión de varios episodios de galantería de Carlos V con la princesa de Salerno y las damas de su séquito. Los legados vénetos constatan: "Questa città è piena di signori gentilhomini et infinita moltitudine di gente, et si sta in feste, maschere et allegrezze...». Finalmente, las cartas informan de las gestiones que estaban realizando ante el César los fuorusciti florentinos y, sobre todo, sus principales valedores, los cardenales Salviati y Ridolfi, sin que pueda deducirse una jerarquía clara de sus prioridades descriptivas entre el otium galante y el negotium político ${ }^{43}$. De hecho, los mismos exiliados toscanos aprovecharían las ocasiones festivas para exponer sus reivindicaciones, como reflejan las descripciones del banquete y las piezas recitadas ante Carlos $\mathrm{V}$ en la villa aragonesa de Poggioreale con motivo del matrimonio de Margarita de Austria y el primer duque de Florencia, Alessandro de Médicis ${ }^{44}$.

En ese marco la sociabilidad femenina, canalizada por los códigos de la galantería, era un ámbito privilegiado para la transacción entre los grupos de poder que pugnaban por acaparar la gracia imperial ${ }^{45}$. Por ello, autores como Minturno invocarían la participación de las damas en los festejos, necesario contrapunto del ideal heroico encarnado por los ejercicios caballerescos:

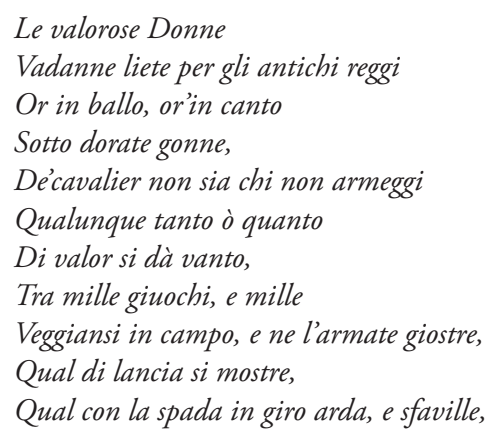

43. ASVe, Archivio Proprio Germania, 1 a.

44. Véase Tobia R. Toscano, «Carlo V nelle delizie aragonesi di Poggioreale. Un academia poetica di nobili napoletani in un raro opusculo a stampa del 1536 , Critica letteraria, no 83 , 1994, pp. 279-307.

45. Véase Giovanni Muto, "Gli spazi femminili nei cerimoniali pubblici napoletani», en Marco Santoro (ed.), La donna nel Rinascimento meridionale, Pisa-Roma, Fabrizio Serra Ed., 2010 e Isabel Torres, Love Poetry in the Spanish Golden Age: Eros, Eris and Empire, Woodbridge, Tamesis, 2013. 
A lo largo de toda la estancia imperial se desarrollaron dos grandes ámbitos festivos. Por un lado, floreció la competición caballeresca en el espacio público de la ciudad, con una fuerte impronta espańola, enriquecida con elementos borgońones e italianos: juegos de cańas, torneos y corridas de toros en la explanada de San Giovanni a Carbonara, lugar tradicional de tales festejos desde la época angevina, o en la nueva plaza delante de Castel Nuovo. Se trataba de revitalizar el ideal caballeresco, adaptado tanto al nuevo arte de la guerra ${ }^{47}$ como, sobre todo, a la creciente espectacularidad cortesana, proyectada incluso en las tradiciones aristocráticas de ámbito más recóndito, como la caza que Garcilaso evocó en la famosa dedicatoria de su I égloga para presentar al virrey Toledo "resplandeciente, armado, / representando en tierra al fiero Marte», pero dedicado a un otium - «de negocios libre»- identificado con la imagen ecuestre y cinegética de resonancias políticas y militares: «en ardiente jinete que apresura / el curso, tras los ciervos temerosos, / que en vano su morir van dilatando $»^{48}$. Esa imagen era especialmente adecuada para quien, como don Pedro, cultivó los más diversos ejercicios caballerescos, desde los toros y cañas hasta las justas y torneos, impulsando la gran tradición ecuestre napolitana que alcanzaría uno de sus momentos culminantes durante la estancia imperial ${ }^{49}$. Por otra parte, se desarrollarían las celebraciones cortesanas más restringidas -banquetes, danzas y mascaradas, el teatro y la música palaciegos-, en las que participó también el virrey, como recuerda su apologético cronista Filonico: "sempre in le giostre dei suoi compagni, nella caccia désuoi aderenti e nelle poste e staffette amorose désuoi seguaci, tenuto in tanta riputazione d'accorto e considerato cortigiano», lo que, según el biógrafo, respondía a una de sus principales ocupaciones: «sendo da lui le giostre bandite, gli esercizi trattati, i gentiluomini intertenuti, le musiche nudrite e le persone virtuoso accarezzate e ridotte in grado di conoscimento e d'onore.... ${ }^{50}$. Esas descripciones intentaban plasmar el ideal expuesto por Baltasar de Castiglione en su Cortesano, publicado en 1528, años después de que Vittoria Colonna -viuda del marqués de Pescara- hiciera circular su manuscrito en Nápoles desde el castillo de la isla de Ischia, corte del gran linaje hispano italiano de los Ávalos y cuya traducción castellana por Juan

46. Rime et Prose del Sig. Antonio Minturno..., pp. 181-182.

47. Véase Amedeo Quondam, Cavallo e cavaliere. L'armatura come seconda pelle del gentiluomo moderno, Roma, Donzelli, 2003.

48. Véase Bienvenido Morros, «El tema de la guerra y la caza en Garcilaso», en José María Díez Borque y Luis Ribot García (eds.), op. cit., pp. 227-240.

49. Véase Carlos José Hernando Sánchez, «'La Gloria del cavallo’. Saber ecuestre y cultura caballeresca en el reino de Nápoles durante el siglo XVI», en José Martínez Millán (dir.), Felipe II (1527-1598). Europa y la Monarquia Católica, Madrid, Ed. Parteluz, 1998, vol. 4, pp. 277-310.

50. Filonico Alicarnaseo (Costantino Castriota), Vita di don Pedro de Toledo, BNN, ms. X. B. 53 , f. $4 \mathrm{v}$. 
Boscán en 1534 difundió en España su culto a la contención de la expresión, al protagonismo del gesto y las buenas maneras mediante la adecuación de alma y cuerpo a un común ideal de elegancia, armonía y distanciamiento ${ }^{51}$. Castiglione configuró un modelo social, asimilado por Garcilaso y Boscán ${ }^{52}$, buscando la buena opinión que debía preceder el saber y valor ${ }^{53}$. Su materialización demuestra que cultura nobiliaria y cultura de la corte - como espacio ${ }^{54}$ y como forma de vivir- ${ }^{55}$ son categorías convergentes y superpuestas, pero distintas y, en ocasiones, incluso enfrentadas ${ }^{56}$.

De hecho, la estancia napolitana de Carlos V refleja también las tensiones causadas por el encuentro entre la corte imperial y la nobleza del reino, cuyos máximos exponentes aglutinaban pequeñas cortes aristocráticas. Estas condicionaron la competencia del esplendor y la magnificencia, empezando por la riqueza y colorido de los atuendos, que desbordaron el modelo de gravedad identificada desde Castiglione con la usanza española ${ }^{57}$, mientras que los espacios celebrativos consagraban la tradición italiana que ligaba el banquete con la música y el teatro en el marco de la naturaleza dominada representado por el jardín, objeto prioritario de las realizaciones suntuarias durante el gobierno virreinal de Pedro de Toledo e inseparable de la cultura arcádica desplegada por las églogas como retrato poético de una sociabilidad sujeta a las tensiones políticas ${ }^{58}$. Esos espacios, como las ceremonias que albergaban y las piezas literarias que en ellos se reflejaban, desbordan el concepto moderno de propaganda, al igual que nuestras nociones de público y privado,

51. Véase Amedeo Quondam, 'Questo povero Cortegiano'. Castiglione, il Libro, la Storia, Roma, Bulzoni, 2000, pp. 67-71.

52. Véase Eugenia Fosalba, «A vueltas con el descuido de Garcilaso y Boscán», en Eugenia Fosalba y Gonzalo Pontón (eds.), La escondida senda. Estudios en homenaje a Alberto Blecua, Barcelona, Castalia, 2012, pp. 147-164.

53. Baltasar de Castiglione, El Cortesano, trad. Juan Boscán, ed. M. Pozzi, Madrid, Cátedra, 1994, Libro II, p. 254. Cf. Giancarlo Mazzacurati, Il Rinascimento dei moderni. La crisi culturale del XVI secolo e la negazione delle origini, Bolonia, Il Mulino, 1985, pp. 194 y ss.; María Coduras Bruna, 'Por el nombre se conoce al hombre'. Estudios de antroponimia caballeresca, Zaragoza, Prensas de la Universidad de Zaragoza, 2015.

54. Véase Marcello Fantoni (ed.), La corte e lo spazio: trentanni dopo, Cheiron, anno XXVIII, no 55-56, 2011.

55. Véase Amedeo Quondam, La forma del vivere. L'etica del gentiluomo e i moralisti italiani, Bolonia, Il Mulino, 2010.

56. Véase Francesco Benigno, «La corte e la foresta. Sulla non coincidenza tra cultura nobiliare e cultura cortigiana», en Chiara Continisio e Marcello Fantoni (eds.), Testi e contesti. Per Amedeo Quondam, Roma, Bulzoni, 2015 (2016), pp. 5-16.

57. Véase Amedeo Quondam, Tutti i colori del nero. Moda e cultura del gentiluomo nell'Italia del Cinquecento, Vicenza, Colla Editore, 2007 y José Luis Colomer y Amalia Descalzo (dirs.), Vestir a la española en las cortes europeas (siglos XVI y XVII), Madrid, Centro de Estudios Europa Hispánica, 2014, 2 vols.

58. Véase Carlos José Hernando Sánchez, «La cultura de la villa entre Nápoles y España: los jardines de los Toledo en el siglo XVI», en Antonio Ernesto Denunzio (coord.), Dimore signorili a Napoli. Palazzo Zevallos Stigliano e il mecenatismo aristocrático dal XVI al XX secolo, Nápoles, Intesa Sanpaolo, 2013, pp. 11-48. 
ajenos a las herramientas mentales de la época. La representación del valor de la persona y de sus actos en el conjunto de un cuerpo social que es a la vez político se sublimaba en ámbitos cortesanos tan plurales como la realidad que encauzaban, fundiendo lo real y lo ideal, lo natural y lo artificioso. Encerrados bajo imágenes de virtud, en las alas del mito o el triunfo, y reflejados por los diversos géneros doctrinales o literarios - desde los libros de caballerías hasta la poesía encomiástica o arcádica, crecientemente valorados por los estudios del ethos nobiliario- ${ }^{59}$, se hallan los conflictos, las estrategias de expansión patrimonial y los resortes de interés y lealtad movidos por un sistema cortesano superpuesto a emergentes conciencias nacionales de las elites aristocráticas que compartían una común cultura política y simbólica ${ }^{60}$.

El banquete es el momento celebrativo por excelencia de los procesos de integración, pero también de los inevitables desencuentros en la competencia por distintas parcelas de poder. En la corte de Borgoña, más que en ninguna otra quizás, el banquete desempeñaba una función central en el complejo ceremonial, como reflejan las celebraciones de la orden del Toisón de Oro ${ }^{61}$. El servicio de mesa constituía el eje de la etiqueta palaciega, según un código que regulaba desde la llegada de los platos al ritmo de distintas músicas hasta la disposición de los aparadores que, dispuestos junto a los muros de la sala del festín, expresaban la ostentación y la competencia aristocrática, pasando por la preparación y adorno de los alimentos, concebidos como espectáculos según una tradición bajomedieval que, avalada por las referencias literarias de la Antigüedad romana, se vería revitalizada por la cultura cortesana desde el siglo XV. De esa forma, el banquete, eje de la sociabilidad aristocrática, acentuó su carácter de celebración de la solidaridad de la élite dirigente y, junto a la cristalización de la cultura material desarrollada por y para la corte, reflejada por los inventarios de bienes - como el del propio virrey Pedro Toledo- ${ }^{62}$, se erigió en síntesis paradigmática del encuentro entre arte y vida para concitar los

59. Véase Fernando Bouza, Palabra e imagen en la corte. Cultura oral y visual de la nobleza en el Siglo de Oro, Madrid, Abada Editores, 2003, así como los estudios reunidos en Mercedes Blanco y Roland Béhar (coords.), Les poètes de l'Empereur. La cour de Charles V dans le renouveau littéraire du XVI siècle, en e-Spania. Revue interdisciplinaire d'études hispaniques médiévales et modernes, no 13 , junio 2012.

60. Véase Juan Hernández Franco, José Antonio Guillén Berrendero y Santiago Martínez Hernández (eds.), Nobilitas. Estudios sobre la nobleza y lo nobiliario en la Europa moderna, Madrid, Ed. Doce Calles, 2014, pp. 113-135. Referencia obligada sigue siendo el clásico estudio de Otto Brunner, Vita nobiliare e cultura europea, Bolonia, Il Mulino, 1982 (1 $1^{\text {a }}$ ed. en alemán: 1949).

61. Véase Jean-Marie Cauchies (ed.), Boire et manger en pays bourguignons (XIVe $-X V T^{e}$ siècles), Neuchâtel, Centre européen d'études bourguignonnes, 2007 y Krista De Jonge, Bernardo García García y Alicia Esteban Estríngana (eds.), El legado de Borgoña. Fiesta y ceremonia cortesana en la Europa de los Austrias (1454-1648), Madrid, Fundación Carlos de Amberes, 2010.

62. Véase Carlos José Hernando Sánchez, «La vida material y el gusto artístico en la Corte de Nápoles durante el renacimiento: el inventario de bienes del Virrey Pedro de Toledo", Archivo español de arte, t. 66, n 261, 1993, pp. 35-56 y Silvia Musella Guida, «Don Pedro Álvarez de Toledo. Ritrato di un principe nell'Europa rinascimentale», Samnium, anno LXXXI-LXXXII, n. s. $21^{\circ}-22^{\circ}, 2008-2009$, pp. $239-253$. 
más diversos recursos artísticos, desde el espacio que lo albergaba, en el palacio o el jardín, hasta la calidad de la vajilla, cuyos materiales nobles se trabajan con el esmero de las mejores joyas de orfebrería y, finalmente, las diversiones que, aureoladas por la literatura clásica, servían de ocasión para el despliegue de la música y las representaciones teatrales ${ }^{63}$.

La ostentación suntuaria y ceremonial del banquete borgoñón, difundida por la corte imperial ${ }^{64}$, se encontró en Nápoles con la tradición italiana del banquete humanístico que insistía en su carácter de momento culto y erudito, signo de refinamiento asociado al diálogo como sublimación literaria del arte della conversazione y a la evocación clasicista que culminaba en las representaciones teatrales. En ese sentido, la corte de los reyes aragoneses de Nápoles había desarrollado a lo largo de la segunda mitad del siglo XV una rica sociabilidad reflejada por diversos autores que iniciaron la codificación del arte de la comida y del servicio de la mesa, desde Giovanni Pontano, con su tratado sobre el Convivium, hasta Ruperto da Nola con su pionero Libro de Cocina $^{65}$. Carlos V había adaptado la etiqueta para reforzar su preeminencia simbólica e integrar a la nobleza de sus diversos territorios, especialmente en los reinos españoles, cuyos grandes adoptaron formas de sociabilidad cortesana de impronta flamenca como el «comer a la borgoñona», que desató fuertes críticas ${ }^{66}$. Estas pudieron nutrirse de una larga tradición, como la que representaba en Francia Nicolás de la Chesnay, quien había traducido en 1507 la obra de Benito de Norcia, con el titulo La nef de la santé ${ }^{67}$. La condena de

63. Véase A. Ch. Fiorato y A. Fontes Baratto (eds.), La table et ses dessous. Culture, alimentation et convivialité en Italie (XIVE $-X V I^{\mathrm{e}}$ siècles), París, Presses de la Sorbonne Nouvelle, 1999; C. Gouédo-Thomas y H. Lebédel-Carbonnel, «Festins de la Renaissance: ce que montrent les images», en E. Latrémolière y F. Quellier (eds.), Festins de la Renaissance. Cuisine et trésors de la table, catalogue d'exposition (Blois 2012), París, Somogy, 2012, pp. 98-119: 118; J. Di Schino, "La Suprema Magnificenza'. Il convito rinascimentale e l'arte del bel servire», en M. Cogotti y J. Di Schino (eds.), Magnificenze a tavola: le arti del banchetto rinascimentale, catalogue d'exposition (Tivoli 2012), Roma, De Luca Editore, 2012, pp. 1-16

64. Véase J. Allard, «Les grands banquets à la cour de Charles Quint», en M. Aurell, O. Dumoulin y F. Thélamon (eds.), La sociabilité à table. Commensalité et convivialité à travers les âges, actes du colloque (Rouen 1990), Rouen, Publications de l'Université de Rouen, 1992, pp. 145-153.

65. Ruperto de Nola, Libro de cozina compuesto por maestre Ruperto de Nola cozinero que fue del serenissimo señor don Hernando de Nápoles: de muchos potages y salsa y guisados para el tiempo carnal y de la quaresma: $y$ manjares y salsas y caldos para dolientes de muy gran sustancia y frutas de sarten y mazapán y otras cosas muy provechosas y del servicio y officios de las casas de los reyes y grandes señores y cavalleros: cada uno como a de servir a su cargo, y el trinchante como a de cortar todas maneras de carnes y de aves y otras muchas cosas en el añadidas muy provechosas... Dirigido al serenissimo rey don Hernando de Nápoles. Compuesto por maestre Ruperto de Nola su cozinero mayor, publicado en catalán, en Barcelona, en 1520 y en castellano, en Toledo, en 1525.

66. Véase Antonio Álvarez-Ossorio Alvariño, «Introducción», en José Martínez Millán (ed.), La corte de Carlos V, op. cit., vol. IV, Los servidores de las casas reales, pp. 7-42.

67. Nicolás de la Chesnay, La nef de la santé, avec le gouvernail du corps humain et la condennation des banquetzs, et la louenge de la dièpte et sobriété, et le traictié des passions de lame traduit de Benott de Norcia, París, Anthoine Vérard, 1507. 
los excesos del banquetear, enmarcada en una corriente anticortesana -desde Antonio de Guevara a Cristóbal de Castillejo- ${ }^{68}$, se extendería en España a autores tan dispares como Tomás de Torquemada ${ }^{69}$ y Pedro de Mercado ${ }^{70}$. Al mismo tiempo, se consolidó un género de Regimientos de sanidad para el consumo de una elite aristocrática ávida de pautas comportamentales para medrar de acuerdo con los nuevos códigos cortesanos. Entre estos ocupaba un lugar creciente la educación de los sentidos, el dominio del cuerpo y la salud, que convertirían el banquete en objeto creciente de atención doctrinal, hasta el punto de que algunos Regimientos se llamarán Banquetes o Convites de sanidad. Una de sus máximas expresiones son los tratados del médico Luis Lobera de Ávila, que acompañó a la corte imperial desde 1520 y en 1530 dedicó a Francisco de los Cobos su pionero tratado dietético Banquete de nobles caballeros, reeditado posteriormente como Vergel de Sanidad ${ }^{1}$. Según Lobera, presente en Túnez y Nápoles, «los cavalleros y señores assi de España y de Francia y de Alemaña como de Italia y otras partes usan agora y tienen mucho en costumbre de hazerse los unos a los otros banquetes y beuer 'autant', que agora dicen.... ${ }^{72}$. El mismo Juan de Valdés se referirá críticamente en su Diálogo de la Lengua, uno de los frutos más trascendentales de la coyuntura napolitana durante la visita imperial, «al juego, al uestir, al uanquetear, que son tres cosas que con la venida de su magestad en Espańa an crecido en tanta manera, que os prometo que se siente largamente por todas partes.... ${ }^{73}$.

De hecho, el arte de la comida se vio consagrado en aquellos meses y constituyó uno de los escenarios preferentes del debate político al concitar los más diversos géneros para canalizar mensajes y expectativas. Así lo demuestran especialmente los convites que siguieron a algunas bodas de estado entonces anudadas por una política matrimonial crucial en el delicado entramado de intereses aristocráticos. El 27 de febrero de 1536 se celebró el matrimonio del príncipe de Sulmona, Philippe de Lannoy, con Isabella Colonna, en el palacio

68. Véase Francisco Márquez Villanueva, -Menosprecio de corte y alabanza de aldea(Valladolid, 1539) y el tema áulico en la obra de Fray Antonio de Guevara, Santander, Servicio de Publicaciones de la Universidad de Cantabria, 1998 y María del Rosario Martínez Navarro, $L a$ literatura anticortesana de Cristóbal de Castillejo: estudio especial del "Aula de Cortesanos" (1547), Vigo, Editorial Academia del Hispanismo, 2016.

69. Antonio de Torquemada, Colloquio que trata de la desorden que en este tiempo se tiene en el mundo y principalmente en la christiandad, en el comer y bever, con los daños que della se siguen, y quan necesario sería poner remedio en ello..., Mondoñedo, Agustín de Paz, 1553.

70. En su «Diálogo de la cena» Mercado reitera el peligro del deleite de la buena comida: Diálogos de filosofía natural y moral, Granada, H. de Mena, R. Robert, 1558.

71. Luis Lobera de Ávila, Vanquete de nobles cavalleros e modo de bibir desde que se levantan hasta que se acuestan, y habla de cada manjar, qué complexión y propiedad tiene e qué daños y provechos haze... [s. 1., s. i., s. a]. La primera edición apareció en Alemania en 1530, BNM, R. 1750 .

72. Luis Lobera de Ávila, Vergel de Sanidad, Alcalá de Henares, Juan de Brocar, 1542, fol. 1.

73. Juan de Valdés, Diálogo de la lengua, ed. José Enrique Laplana, Barcelona, Crítica, 2010, p. 233. Cf. Encarnación Sánchez García, «El Diálogo de la lengua a la luz de la identidad de 'Martio' (Bernardino Martirano)», en Encarnación Sánchez García (dir.), Rinascimento meridionale..., pp. 137-178. 
del príncipe de Bisignano ${ }^{74}$, y un día después el de la hija natural del César, Margarita de Austria, con el duque de Florencia Alessandro de' Medici en Castel Capuano. Este último enlace, por el rango de los contrayentes, revistió la máxima suntuosidad, patente en el banquete que siguió a la ceremonia, adornado por las habituales figuras de azúcar ${ }^{75}$, que remitía a un género de escultura culinaria, culminación del esplendor figurativo desplegado en la mesa, microcosmos simbólico del lenguaje heráldico y virtuoso donde cobraban forma efímera los sueños atemporales alimentados por la sociabilidad aristocrática ${ }^{76}$ en una espectacularidad que obliga a relativizar la presunta excepcionalidad de la tópica teatralidad barroca en la que había de destacar la corte española ${ }^{77}$.

Alonso de Santa Cruz cuenta en su Crónica, tras referirse a la boda de Alessandro y Margarita, que «el Marqués de Villafranca, virrey de Nápoles, hizo un muy solemne banquete y convidó a Su Majestad y a mas de 150 damas y siete seńoras, todas princesas, que comieron con él a su mesa, y la cena se comenzó a prima noche y duró hasta cerca del día, donde danzaron todas las damas con más de treinta caballeros que hubo enmoriscados, muy ricamente aderezados, y en ellos entraron Príncipes y Duques y Marqueses; hubo en el banquete muchas viandas y muchas diversidades de frutas» ${ }^{78}$. El evidente intento

74. Según el conde Maffei: «Hieri sera nel Pallazzo del Sr. Principe de Bisgnano furno fatte le sponsalitie della Sra. Isabella Colonna et Principe di Sulmona, doue S.Mt. con tutta la corte ui fu, et assisteuano tutte queste Signore Principesse et altre Signore dalla Salernitana et Sra. Giulia Gonzaga in fuori». Las resistencias de la novia fueron vencidas por la presión del Emperador, que intervino también en el complicado acuerdo de la dote, en el que se veían afectados los intereses encontrados de las diversas ramas de los Colonna y Gonzaga: «per quanto intendo questa Signora sposa non si contentaua troppo di casarse col Principe di Sulmona ma li prieghi di S.Mt. l'hanno astretta et da per dote $v \mathrm{~m}$. scudi d'entrata de quelli beni che tiene in Campagna di Roma et che li occupa il S. Ascanio, et per pegno de xx m. scudi una terra de queste che ha nel Regno la qual il pto. Principe goderà fin tanto chel $S$. Vespesiano Gonzaga li dia li $x x \mathrm{~m}$. scudi. Il resto del stato che ha qua et quel che ha dalle parte di là, uole che sia del pto. sr. Vespasiano, godendo peró lei finche la uiue», Niccolo Maffei al duque de Mantua, Nápoles, 28 de febrero de 1536, ASMa., Archivio Gonzaga, busta 812, f. 251.

75. Maffei escribía el mismo día 28 de febrero: «Questa sera se fanno in Castel Capoano le sposalitie della figliuola di Su Mt. et del S. Duca Alexandro doue sonno connitate trecento Signore de titulo nobile». El enlace se hizo coincidir con el carnaval, lo que resaltó el carácter lúdico de los festejos, como asimismo informaba Maffei al duque de Mantua el 2 de marzo: «Martedi che fu il giorno di Carnouale tutte queste Signore Napolitane, che fu un numero grande, se ritrouorno in Castel Capuano, doue si fecero le sposalitie della Figliuola di S.Mt. et sig. Duca Alexandro, con gran solennità, et allegrezza, et della pta. Mt. et del pto. Duca, et de tutti quelli che ui erano presenti subito sposata comparse una supperba colatione de uarij sorte de confetti et alcune imagine di Zuccaro che comparsero molto bene, et dicono che questa colatione è costata mille scudi», ASMa., Archivio Gonzaga, busta 812, f. 256v.

76. Véase June Di Schino, «La rinascita delle arti. La divina piegatura e il trionfo di zucchero", en Magnificenze a tavola, op. cit., pp. 83-90.

77. Véase Michel C. Simón, «La théâtralité des repas royaux dans l'Espagne des XVIe et XVII ${ }^{\mathrm{e}}$ siècles», en La sociabilité à table, op. cit., pp. 159-165.

78. Alonso de Santa Cruz, Crónica del Emperador Carlos V, ed. Antonio Blázquez y DelgadoAguilera y Ricardo Beltrán y Rózpide, Madrid, Real Academia de la Historia, 1922, vol. 3, p. 316. Cf. Filonico Alicarnaseo, op. cit., f. 15. 
virreinal de contrarrestar el esplendor de los festejos aristocráticos recurriendo también a la galantería, el disfraz, la danza y el banquete -cuya asociación parecía ineludible-, se vio reforzado por similares iniciativas de sus principales colaboradores. Así, otra crónica, ya del siglo XVII, describe la fiesta organizada para el Emperador en la casa de la hija y heredera de Hernando de Alarcón, Isabel, casada con Pedro González de Mendoza. La dama pidió al monarca "que entrasse en vn salón que estaua aderezado, para que descansasse, y luego que tomo la silla salieron los nietos del Señor Alarcon, y juntamente con sus criados y criadas representaron vna Comedia, y le siruieron con otros festejos de Saraos, y Musicas, de que se mostro muy gustoso el Emperador. Despues de esto sacaron muchos regalos que estauan preuenidos para su Magestad y para los señores que le acompañauan....» ${ }^{79}$. Que esas piezas teatrales podían ser algo más que representaciones de ocasión se deduce de la misma emulación que llevaba a organizarlas. Su significado político nos adentra por los caminos de palacios y jardines poblados por ninfas y pastores tan poco inocentes como la música que los acompañaba.

\section{El CANTO ACORDADO DE LA ÉGLOGA POLÍTICA}

Cuando la estética es poder en sí misma, la comprensión global -literaria, artística y social- de las celebraciones napolitanas durante la estancia imperial solo puede completarse desde el conocimiento de las representaciones teatrales y parateatrales de sentido político, objeto de creciente interés historiográfico ${ }^{80}$, así como su culminación en la égloga y su difusión en el ámbito de la Monarquía de España ${ }^{81}$. La égloga dramática es un género indisociable de la sociabilidad aristocrática y cortesana, donde se configuró como expresión de intereses políticos, a veces subyacentes bajo el lenguaje alegórico del clasicismo y en otras ocasiones explícitamente invocados en el prólogo o el propio argumento de las piezas ${ }^{82}$. La riqueza del discurso simbólico potenciado por el desarrollo de la cultura de corte encontró en ese género en apariencia evasivo

79. Alonso Suárez de Alarcón, Comentarios a los hechos del Señor Alarcón, Marqués de Valle Siciliana y de Renda y de las guerras en que se halló por espacio de 58 años, Madrid, Diego Díaz de la Carrera, 1665, pp. 437-438.

80. Véase Teresa Ferrer Valls, «De los entremeses de circunstancias políticas a las piezas dramáticas de circunstancias políticas: el preludio del drama histórico barroco» en Francesc Massip (ed.), Formes teatrals de la tradició medieval. Actes del VII Col.loqui de la Société Internationale pour l'Étude du Théatre Médiéval (Girona 29 de junio a 4 de julio de 1992), Barcelona, Institut del Teatre-Diputació de Barcelona, 1995, pp. 417-424.

81. Véase Aurora Egido, "Sin poética hay poetas”. Sobre la teoría de la égloga en el Siglo de Oro", Criticón, no 30, 1985, pp. 43-77 y Soledad Pérez-Abadín Barro, Resonare silvas: la tradición bucólica en la poesía del siglo XVI, Santiago de Compostela, Universidade de Santiago de Compostela, 2004.

82. Véase M. A. Pérez Priego, «La égloga dramática», en B. López Bueno (ed.) La égloga, Sevilla, Servicio de Publicaciones de la Universidad de Sevilla, 2000, pp. 77-89. 
un canal privilegiado para expresar en distintos registros sus expectativas más recónditas y más evidentes. Por ello, resulta revelador de la asimilación española de los presupuestos sociales del discurso cortesano el hecho de que el género pastoril encontrara una temprana formulación en el ambiente de la aristocracia castellana, de la mano de autores que, más allá de la modernidad de sus fórmulas poéticas, ligan en un espacio común de fiesta y mecenazgo la obra pionera de Juan del Encina en la corte del II duque de Alba Fadrique Álvarez de Toledo con la de Garcilaso en la de su nieto y heredero Fernando o en la de su hijo segundo, el virrey de Nápoles Pedro de Toledo ${ }^{83}$.

La culminación de la dramatización cortesana del discurso pastoril es la égloga política que, no por casualidad, tiene también en Nápoles -epicentro de la poesía como práctica del poder, cultivada en la corte aragonesa por Giovanni Pontano y otros $-{ }^{84}$ sus primeras formulaciones, vinculadas a la actualidad, como en la obra de Jacopo Sannazaro sobre la celebración de la toma de Granada ${ }^{85}$. Poco después encontramos otra égloga política en un autor castellano, Francisco de Madrid, en el contexto del enfrentamiento de Fernando el Católico y Carlos VIII de Francia al inicio de las Guerras de Italia que llevaría a la caída de la dinastía aragonesa de Nápoles. En una reveladora pieza, Madrid hacía aparecer en escena al propio rey Fernando bajo el nombre de Fortunado -considerado la primera aparición de la figura del rey en el teatro español-y Carlos VIII como Peligro $^{86}$. Un momento culminante en ese diálogo pastoral entre las cortes napolitanas y españolas se produciría en 1503, cuando se representó en Nápoles un drama alegórico político en latín, obra del humanista Girolamo Morlino, quizás ante la presencia del Gran Capitán, Gonzalo Fernández de Córdoba, primer virrey español, que acababa de hacer su entrada en la ciudad caput regni mientras la guerra con los franceses continuaba en varias provincias. La farsa, destinada según declara el autor en el prólogo a «calmar los ánimos y alejar angustias», dada la incertidumbre que aún se cernía sobre el trono napolitano,

83. Véase Álvaro Alonso, «Poesía pastoril entre Encina y Garcilaso», en Cesc Esteve (ed.), El texto infinito. Tradición y reescritura en la Edad Media y el Renacimiento, Salamanca, SEMYR, 2014, pp. 247-270.

84. Véase Matteo Soranzo, Poetry and Identity in Quattrocento Naples, Nueva York, Routledge, 2014.

85. Véase Cecilia Nocilli, "La presa di Granata e Il triunfo de la fama. Danza, musica e politica nella farsa di Iacopo Sannazaro (1492)», en Danielle Boillet y Alessandro Pontremoli (eds.), Il mito d'Arcadia. Pastori e amori nelle arti del Rinascimento, Florencia, Olschki, 2007, pp. 167-188. Cf. Pasquale Sabbatino (ed.), Iacopo Sannazaro. La cultura napoletana nell'Europa del Rinascimento, Florencia, Olschki, 2009 y Cristiana Anna Addesso, Teatro e festività nella Napoli aragonese, Florencia, Olschki, 2012.

86. Véase Federica Accorsi, «La Égloga de Francisco de Madrid: un ensayo bucólico de finales del xv», en Natalia Fernández y María Fernández (eds.), Literatura medieval y renacentista en España: líneas y pautas, Salamanca, SEMYR, 2012, pp. 333-340; Álvaro Bustos, «Fernando el Católico frente a Carlos VIII (1492-1498): diplomacia y disfraz pastoril en la Égloga de Francisco de Madrid», en Álvaro Bustos y Elena Di Pinto (eds.), José María Díez Borque (dir.), Miscelánea teatral áurea, Madrid, Visor, 2015, pp. 47-73 y Álvaro Bustos Táuler, «Juan del Encina, Francisco de Madrid y el género de la égloga política sayaguesa», Criticón, no 126, 2016, pp. 15-29. 
estaba protagonizada por Protesilaus -máscara de Fernando el Católico-, que luchaba con Orestes -Luis XII de Francia- por los favores de la ninfa Leucasia, imagen de Nápoles. El pérfido Orestes, auxiliado por su amigo Pontico -el mar imprevisible y amenazante- era finalmente derrotado por el héroe, en cuya ayuda descendían cuatro divinidades del Olimpo: Venus, Palas, Marte y Mercurio, para entonar finalmente la loa del monarca, amante, vencedor y fiel exponente de su nación: "Iberia semper / inclyta bellatrix, ducibus et nobilis armis... ${ }^{87}$. De esa forma, la conquista de Nápoles aparecía asociada a las personificaciones de la sangre-Venus-, la sabiduría-Palas-, la guerra-Martey el interés -Mercurio-, puestas al servicio del Rey Católico para reclamar la polémica herencia continental italiana de Alfonso V el Magnánimo frente a los recursos, inicialmente superiores, del Rey Cristianísimo. Ese Olimpo de la conquista mezclaba con moderno realismo político el tradicional principio dinástico de legitimación con la fuerza de los hechos consumados a través de un proceso bélico presidido por la renovación del arte militar y por el entramado de intereses comerciales, aristocráticos y faccionales que sustentó las diversas agregaciones territoriales vividas en Europa Occidental desde finales del siglo XV. Así, la antigua invocación a Venus resultaba más inseparable que nunca de la aún más frecuente y veleidosa a Marte, cuya sombra iba a oscurecer el brillo de la primera en los principales episodios expansivos de las grandes monarquías gracias a los nuevos instrumentos puestos a su servicio por los audaces vuelos de Palas y Mercurio. Serían estos -recursos técnicos y materiales, lealtades pactadas, mudables y superpuestas, consensos reconstruidos en las diversas esferas de poder de la república cristiana- los que reforzarían las armas de Marte para compensar los frágiles argumentos de Venus en los procesos de conquista que, como en Nápoles, solo podían apelar tangencialmente al habitual recurso a la cruzada para justificar la anexión de un territorio cristiano desposeyendo a sus monarcas legítimos.

Esa legitimidad era tan necesaria para el príncipe agresor como para la cambiante lealtad de las sociedades políticas cuyas divisiones provocaron la caída de sus soberanos tradicionales. Por eso, en 1513 la entrada de Fernando el Católico en Valladolid desplegó un novedoso programa a la antigua para celebrar la reciente conquista de Navarra mediante dos arcos triunfales, dedicados a la Victoria y a la Iglesia, donde las imágenes imperiales romanas, inspiradas en las que pudo contemplar el mismo monarca durante su entrada napolitana en 1506, servían para exaltar las virtudes cristianas del príncipe asociando sus triunfos sobre los infieles en Granada y África con los obtenidos sobre los franceses, ahora convertidos en cismáticos, al expulsarlos de Nápoles y Navarra ${ }^{88}$. En el mismo sentido, durante las honras fúnebres de Fernando,

87. Véase Benedetto Croce, I teatri di Napoli, ed. Giuseppe Galasso, Milán, Adelphi, 1992, pp. 27-28 y Francisco Elías De Tejada, Nápoles Hispánico, Madrid, Ediciones Montejurra, 1958, vol. I, pp. 331-334.

88. Véase Tess Knighton y Carmen Morte, «Ferdinand of Aragon’s Entry into Valladolid in 1513: the triumph of a Christian King», Early Music History, no 18, 1999, pp. 119-163: 162. Cf. Miguel Falomir Faus, «Entradas triunfales de Fernando el Católico en España tras 
organizadas en febrero de 1516 por la corte de su nieto y sucesor en Bruselas, el cortejo que recorrió la ciudad hasta la colegiata de San Miguel y Santa Gúdula estuvo presidido por un carro triunfal que portaba, sobre armaduras colgadas de un árbol de oro a modo de trofeos clásicos, la representación de los reinos conquistados por el monarca difunto, encabezados por la sirena Parténope, símbolo de Nápoles, y seguidos por una montaña en alusión a Navarra, un matorral a Jerusalén -cuya corona cruzada iba aneja a la napolitana e infundía una legitimación adicional a todas las demás- y una granada al reino nazarín ${ }^{89}$. De esa forma se resaltaba el protagonismo de los territorios que formaban la parte más discutida de la herencia recibida por el joven Carlos de Austria.

En la misma coyuntura sucesoria la égloga política volvió a concretarse en una pieza del máximo relieve ceremonial como es la Égloga Real, representada en Valladolid a finales de 1517 y compuesta por el bachiller Fernando de la Pradilla ${ }^{90}$. Según declara en el prólogo este «cathedrático de Santo Domingo de la Calçada», discípulo de Nebrija en Salamanca ${ }^{91}$, que ya había escrito unas Coplas latinas y españolas de la llegada del Rey Don Phelippe y Doña Joana en 1502, la «compuso primeramente en latín y por mas seruir a su alteza la conuertio en lengua castellana trovada, presentola en la muy noble villa de Valladolid en fin del mes de deziembre del año próximo de quinientos y diecisiete. Introduzense quatro pastores Telepho, Guilleno, Crispino y Menedemo los quales después que han hablado algunas cosas en alabanza de su alteza prouocan a los estados de los hispanos a que uengan a besar las manos», todo ello "en pastoril estilo y de arte mayor ${ }^{92}$. La obra, que desdobla la realidad cortesana del solemne acto de acatamiento al nuevo monarca celebrado en la ciudad castellana por los representantes de todas las élites del reino, se inserta en una corriente de producción literaria que constituye una fuente esencial de la historia política y el universo simbólico del poder ${ }^{93}$. En la misma línea se inserta el segundo gran momento de celebraciones parateatrales, con motivo de las fiestas organizadas

la conquista de Nápoles», en La visión del mundo clásico en el arte español, Madrid, Editorial Alpuerto, 1993, pp. 49-55.

89. Véase Fernando Checa Cremades, Carlos V. La imagen del poder en el Renacimiento, Madrid, Ediciones El Viso, 1999, pp. 325-328.

90. Véase José María Díez Borque, «Teatro del poder en la España del siglo XVI: la imagen del emperador Carlos V», en Pedro M. Piñero Ramírez y Christian Wentzlaff-Eggebert (eds.), Sevilla en el Imperio de Carlos V: encrucijada entre dos mundos y dos épocas, Sevilla, Universidad de Sevilla-Universidad de Colonia, 1991, pp. 163-184.

91. Véase F. González Ollé, "El Bachiller de la Pradilla, humanista y dramaturgo", Romanistisches Jahrbuch, vol. XVII, 1966, pp. 285-300; Silvia González-Sarasa Hernáez, «Un retórico riojano en el Siglo de Oro riojano: el Bachiller de La Pradilla. Recordatorio biográfico y estudio editorial de su producción", Berceo, no 163, 2012, pp. 83-264; Pedro Martín Bańos, Julián Martín Abad y Pedro M. Cátedra, La obra del Bachiller de la Pradilla en gramática, poesía y rhetórica (Logroño, c. 1503), Salamanca, Ediciones Universidad de Salamanca, 2013.

92. Egloga Real, BNM R/39834.

93. Véase Víctor Infantes, «Poesía teatral en la corte: historia de las églogas de Diego Guillén de Ávila y Fernando del Prado», en Alan Deyermond e Ian Macpherson (eds.), The Age of the Catholic Monarchs, 1474-1516. Literary Studies in Memory of Keith Whinnom, Liverpool, University Press, 1989, pp. 76-82. 
tanto en Espańa como en Nápoles por la elección imperial de Carlos V. En 1519 la Plaza Mayor de Valladolid fue escenario de otra gran representación donde se evocaba la elección imperial y la próxima coronación en Aquisgrán ${ }^{94}$, mientras en Barcelona asumía un papel relevante la música, así como en Nápoles, donde el poeta Girolamo Britonio publicó una Ordene et recollettione de la festa fatta in Napoli per la nova havuta de lo Imperatore Carlo V, y el humanista Pietro Gravina describió en su epistolario los banquetes y bailes organizados por el virrey Ramón Folch de Cardona con la participación de los principales caballeros y damas de la aristocracia local ${ }^{95}$. A esas representaciones se unirían nuevas entradas del soberano en Flandes, España y, desde 1529, la propia Italia, como otros tantos jalones de una escenificación cortesana que culminaría en el gran itinerario triunfal de 1535. En ese sentido destaca la entrada en Valencia en 1528, organizada por el duque de Calabria Fernando de Aragón, heredero del último rey independiente de Nápoles y virrey de Valencia desde 1526. El duque de Calabria, que durante su largo gobierno en la ciudad del Turia organizó una corte de fuerte impregnación teatral, concibió la entrada del César por las Torres de Quart con un sentido escenográfico que, no por convencional, deja de recordar al desplegado unos años después en la napolitana Porta Capuana. La puerta de la muralla por donde entró Carlos se revistió con un arco de madera cubierto por telas pintadas. Sobre ella se dispusieron dos corredores para los ministriles y trompetas, así como una bóveda que se abrió para permitir el descenso de tres ángeles que entregaron al monarca el cetro, la corona y las llaves de la ciudad. En el recorrido del cortejo, que siguió el de las procesiones del Corpus Christi -en este caso incorporada también a la celebración- como nueva manifestación de la sacralidad regia, se erigieron arcos vegetales y se cumplió el ritual establecido, desde la ida de las autoridades municipales para recibir al Emperador antes de su entrada, con el correspondiente besamanos en señal de acatamiento, y la espera del monarca en un lugar cercano, fuera de las murallas, para dar tiempo a la terminación de los preparativos, hasta la ostentación del caballo lujosamente enjaezado y el palio no menos suntuoso cuyos portadores, elegidos entre los máximos representantes municipales, dieron lugar a uno de los habituales conflictos de precedencia que Carlos saldó eliminando los dos puestos en litigio ${ }^{96}$. En esa

94. Véase Javier Espejo Surós, «Carlos sobre las tablas: notas a la anónima Representación sobre la elección imperial (ca. 1519)", en Murcia: Biblioteca Saavedra Fajardo de Pensamiento Político Hispánico, 2007, http://saavedrafajardo.um.es/WEB/archivos/NOTAS/RES0077.pdf.

95. Emilio Ros-Fábregas, «Music and Ceremony during Charles V's 1519 Visit to Barcelona», Early Music, vol. 23, no 3, agosto 1995, pp. 374-391; Tobia R. Toscano, "Carlo V nella letteratura e nella publicistica napoletane (1519-1536)", en Juan Luis Castellano y Francisco Sánchez Montes (coords.), Carlos V. Europeísmo y Universalidad, Madrid, Sociedad Estatal para la conmemoración de los centenarios de Felipe II y Carlos V, 2000, vol. I, pp. 265-266 y Carlos José Hernando Sánchez, El reino de Nápoles en el Imperio de Carlos V. La consolidación de la conquista, Madrid, Sociedad Estatal para la conmemoración de los centenarios de Felipe II y Carlos V, 2001, pp. 253-256.

96. La escenificación del descenso de los ángeles, aunque puede remitir a algunos ejemplos en las entradas italianas, parece más próxima a los cuadros vivientes medievales, así como a las 
ocasión, el duque de Calabria pudo proponer a su común antepasado Alfonso $\mathrm{V}$ de Aragón como modelo de gobierno para el Emperador, al que regaló algunos de los mejores ejemplares manuscritos de la biblioteca de este que había portado desde Nápoles. Si en Valencia la música se integró en el ingreso a través de resonancias litúrgicas, otras formas de teatralidad se ensayaron en diversas entradas durante los años siguientes. Proliferaron así piezas breves, como la de Santa Engracia de Hernando de Basurto, representada en 1533 para recibir a la emperatriz Isabel en una de las puertas de Zaragoza, bajo la arquitectura efímera de un arco que incluía cánticos ${ }^{97}$.

Más relevante aún parece haber sido el papel de la música en Nápoles, tanto en la ceremonia de la entrada como en los festejos de los meses siguientes. Nuevamente, la tradición de la corte aragonesa pudo actuar como inspiración para revitalizar tendencias arraigadas en la corte imperial en torno al protagonismo ceremonial de la capilla borgoñona. "Como gema de rubí en una joya de oro» sería la música en un banquete, según escribió en la corte aragonesa de Nápoles el músico flamenco Johannes Tinctoris, citando un versículo del Eclesiastés junto a otras referencias de Isaías, Horacio, Virgilio y Quintiliano $^{98}$. La música respondía a las necesidades de la corte y del ritorno all'antichità impulsado por los studia umanitatis ${ }^{99}$, como reflejaba su gran despliegue en los banquetes de las cortes pontificia y cardenalicias en Roma, así como en otras cortes italianas ${ }^{100}$. Pero era también un componente esencial de la composición poética, como atestiguan Sannazaro y el propio Garcilaso,

tradiciones litúrgicas de particular raigambre en el área levantina, como en el conocido Misteri de Elche. Una descripción sucinta de la entrada se encuentra en el poema de Vasco Díaz de Frexenal «Triumpho Receptorio valentino sobre la Triumphante entrada del invictissimo Carlo quinto emperador semper Augusto en la inclita ciudad de Valencia", contenido en la obra del mismo autor Los veinte Triumphos, publicada en Valencia después de 1530. Sobre esta obra, véase Atanasio López, «Los veinte Triumphos hechos por Vasco Díaz de Frexenal», separata del Boletín Arqueológico de la Comisión Provincial de Monumentos Históricos y Artísticos de Orense, 1935 y Los Austrias. Grabados de la Biblioteca Nacional, Madrid, 1993, pp. 64-66. Cf. M. P. Monteagudo Robledo, «La entrada y juramento de Carlos I en Valencia (1528). El lenguaje simbólico como expresión de la imagen del poder real en los albores del estado moderno", en XV Congreso de Historia de la Corona de Aragón, Actas: El poder real en la Corona de Aragón (siglos XVI-XVII), Zaragoza, Departamento de Educación y Cultura de Aragón, 1996, t. I, vol. 3, pp. 387-400.

97. Véase Alberto del Río, Teatro y entrada triunfal en la Zaragoza del renacimiento. Estudio de la representación del Martirio de Santa Engracia de Fernando Barsuto en su marco festivo, Zaragoza, Ayuntamiento, 1988.

98. "Sicut enim carbunculus duplicat splendorem auri, ita melodia iocunditatem convivii», Johannes Tinctoris, Complexus effectuum musices, en Opera theoretica, ed. Albert Seay, 3 vols., 2 tomos, [Roma] 1975-1978, "Corpus scriptorum de musica, vol. 22», II, p. 176.

99. Véase Jorge Bergua Cavero, La música de los clásicos. Versiones de la poesía antigua, de la Edad Media al Renacimiento tardio, Valencia, Pre-textos, 2012.

100. Véase Anthony M. Cummings, The Politicized Muse. Music for Medici Festivals, 1512-1537, Princeton, Princeton University Press, 1992; Stefano Lorenzetti «At every gesture from the lord': Music at banquets, a cornucopia of the senses», Predella. Journal of visual arts, $n^{\circ} 33$, 2013, pp. 21-42 y Philippe Canguilhem, «I musici convivi di Roma (1530-1540) e la dimensione sonora del banchetto nel Rinascimento», ibid., pp. 117-132. 
«muy gentil músico de la harpa» al decir de Gonzalo Fernández de Oviedo ${ }^{101}$. En ese marco, la entrada de Carlos V en Nápoles puede entenderse también como una fiesta musical ${ }^{102}$. Según Cesare Corsi, durante la visita imperial se habrían interpretado por vez primera canciones del género de la villanesca a la napolitana, de creciente eco en toda Europa. Así lo testimoniaría la publicación, poco después de la marcha del Emperador, de dos libros de intavolatura per liuto, obra del compositor Francesco Canova da Milano, que incluían una reveladora dedicatoria al virrey de Nápoles Pedro de Toledo ${ }^{103}$, además de la primera colección, anónima, de canciones villanesche ${ }^{104}$. El mismo estudioso ha destacado los episodios musicales de la entrada a partir de las descripciones entonces compuestas. Así, Giovan Domenico Lega, en su opúsculo Il glorioso trionfo et bellissimo apparato ne la felicissima entrata di la maestà cesarea in la nobilissima citta di Partenope..., publicada pocos días después de la ceremonia, habla de una compañía de pífanos y trompetas ${ }^{105}$. Doce trompeteros, vestidos con los colores de la ciudad, precedían a los Electos de los seggi, que representaban el gobierno urbano. Según una crónica manuscrita, otras trompetas, cornetas y pífanos sonaron sobre la Porta Capuana cuando el Cesar la franqueó, en tanto que el mismo Lega informa de que los dioses marinos representados en el arco de triunfo erigido ante esa entrada principal de la ciudad portaban "buccine in mano", así como tres sirenas con instrumentos para cantar en honor del soberano y la inscripción Solus eris nobis cantandus Semper in orbe. A ellas se unían las imágenes de "molte nimphe che sonavano». Incluso las estatuas de los colosos, que constituyeron el eje del discurso alegórico, ostentaban atributos musicales, como el cuerno de la Fama en el seggio de Nido o el cuerno marino de Portunno en el seggio de Porto. Con todo, era la figura de la sirena Parténope, alzada delante de la Porta Capuana como primer hito del itinerario triunfal, la que concentraba las mayores alusiones musicales. Se trataba de una mujer con la parte inferior del cuerpo en forma de águila y no de pez, según el modelo antiguo y el simbolismo del poder actualizado por el escudo imperial. La sirena, que daba nombre a la ciudad, como pagana patrona de una tradición

101. Véase Maria Carolina Oss-Cech Chiacchia, The Music in Garcilaso de la Vega's Poetry and his Poetry in Music. A Musico-Poetic Interchange Between Sixteenth-Century Spain and Italy, tesis doctoral, Alberta, University of Calgary, septiembre 2014, p. 56.

102. Véase Cesare Corsi, «Musica reale e immaginaria nelle feste per la visita a Napoli di Carlo V», en Enrico Careri y Pier Paolo De Martino (eds.), Napoli Musicalissima. Studi in onore del $70^{\circ}$ compleanno di Renato Di Benedetto, Lucca, Libreria Musicale Italiana, 2005, pp. 5-27.

103. Francesco da Milano, Intavolatura de viola over lautto..., primo et secondo libro della fortuna, Nápoles, Sultzbach, 1536. Existe ed. facsímil a cargo de Arthur Ness, Ginebra, Minkoff, 1988. Cf. Yves Giraud, «Deux livres de tablature inconnus de Francesco de Milano», Revue de Musicologie, t. LV, no 2, 1969, pp. 217-219.

104. Canzoni villanesche alla napolitana, Nápoles, Johannes de Colonia, 1537. Cf. Donna G. Cardamone, «De Debut of the Canzone Villanesca alla Napolitana», Studi Musicali, anno IV, 1975, pp. 65-130 e id., The Canzone Villanesca alla Napolitana and Related Forms 1537-1570, Ann Arbor, UMI Research Press, 1975.

105. Véase Tobia R. Toscano, «Le Muse e i Colossi...», que transcribe completo el texto de Lega. 
mítica, aparecía tocando una lira da braccio. Tales representaciones estáticas de la interpretación musical cobran vida en la evocación literaria construida por otro de los autores que narraron la entrada. Se trata del poema en octava rima Il Trionpho di Carlo Quinto a cavallieri et alle donne napoletane de Giovan Battista Pino, publicado en Nápoles el 8 de septiembre de 1536. Pino, que más tarde se enfrentaría al virrey por componer unos emblemas críticos contra su gobierno en los aparatos efímeros del día del Corpus de 1548, se prodigó en elogios de don Pedro y su familia ${ }^{106}$, cuya trascendencia en la interpretación simbólica del evento ha sido justamente subrayada por Corsi. Pino sigue a Lega en sus elementos descriptivos, pero añade una dimensión de ficción que parece responder al habitual juego cortesano del desdoblamiento de lo real. Inspirado en los Trionfi de Petrarca, de obligada referencia en ese escenario, el poema parte de una visión auditiva imaginada por el autor mientras pasea junto al río Sebeto. Allí escucha un canto procedente de la sirena Parthénope, que lo traslada al espacio triunfal presidido por su estatua y la del río ante la Porta Capuana. La sirena lo acompañará en su visita por los aparatos efímeros que habían transformado la gran urbe en una ciudad ideal, impregnada por las expectativas de todos los estamentos integrantes de su sociedad política en el momento crucial de recibir a su señor y asumir por tanto un propio destino, legitimado por los discursos de la historia y el mito como transfiguración de la presunta identificación entre los intereses de la Corona y el reino. El espacio, representado por el río Sebeto, y el tiempo, encarnado por la mítica sirena fundadora, reciben al César entonando cantos que ilustran las inscripciones latinas grabadas en sus estatuas. Los versos que Pino pone en boca de Parthénope mientras toca su lira evocan un paisaje inequívocamente pastoril al convocar a las ninfas para que "dal più secreto / Luoco talhor, e talhor da la riva / Ve specchiate nell'onde di Sebeto...", mientras este responde con otra canción convocando "ale sue Nimphe citadine» para que la sirena prosiga su canto. El dios fluvial despliega los tópicos del género arcádico en un marco mitológico destinado a una larga continuidad en la corte virreinal:

Cloride vagha, e la leggiadra flora
Et ogni Nimpha che te prima honora,
Satiri allegri, \& voi silvani desti
In compagnia di fauni al correr pronti,
Chavvezzi sete andar cacciando in questi
Herbosi, ameni e dilettosi monti,
A che non ite homai veloci, e, presti
Raccogliendo le greggie che nei fonti
Bevendo, si resguardan che con voi
Venghino à udir lee lode deli heroi.
Leggiadre, ornate, \& vaghe pastorelle

106. Sobre la edición, salida de las prensas de Giovanni Sultzbach, véase Manzi, Annali di G. Sultzbach, Florencia, Olschki, 1970, pp. 67-68. Hay una versión manuscrita: Il Triompho del Imperatore Carlo V discritto di Gio. Batt. Pino nel Ingresso che egli fece in Napoli nel 1535, BNN, Spinelli, IV, B10, ff. 187-200. 


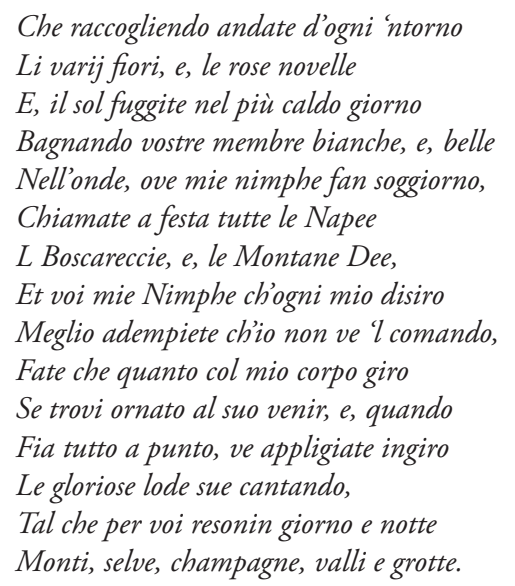

El paisaje napolitano, convertido desde Pontano y Sannazaro en arquetipo de la nueva Arcadia, despliega toda su poesía telúrica para recibir al Emperador con ecos que recuerdan a las ninfas garcilasianas, así como la presencia de Clorida parece un precedente del célebre poema ecfrástico compuesto en 1547 por Tansillo para el virrey Toledo. La música, como señala Corsi, sirve en esta ocasión para animar ese paisaje con la escenificación de un grupo orquestal presidido por la sirena con la compañía de dos ninfas «cuasi a costituire quel trio di sirene che in una delle immagini dell'arco di trionfo mostrava a Carlo il Desiderio di cantarne nel mondo le lodi...", todo lo cual, según el mismo autor, podría hacer pensar que las inscripciones puestas bajo las estatuas de Sebeto y Parthénope estuvieran realmente destinadas a ser cantadas durante la entrada imperial, "quasi nella forma [...] di una minuscola egloga musicale» ${ }^{107}$.

Pero el poema de Pino es también un manifiesto del protagonismo femenino en el recibimiento del guerrero victorioso que, a su vez, se convierte en ocasión celebrativa de un esplendor aristocrático dotado de significado político en las estrofas dedicadas a la mujer y las hijas del discutido virrey. Si este mismo aparece reveladoramente exaltado en la compañía del Emperador, frente a su ausencia en otras composiciones o festejos organizados por la nobleza local, mayoritariamente contraria a su continuidad en el gobierno, su mujer, la II marquesa de Villafranca, María Osorio Pimentel -llegada a Nápoles, junto a sus hijas, apenas un año antes-, aparece revestida por los atributos de la ejemplaridad aristocrática que ya la habían hecho merecedora en 1524 de la dedicatoria de una obra tan representativa de la piedad nobiliaria como el Espejo de ilustres personas del franciscano Alonso de Madrid y su retrato poético despliega la habitual síntesis de virtudes morales y físicas que la acabarían inmortalizando como la «ilustre y hermosísima María» a la que Garcilaso había de dedicar su III égloga, en una suerte de justificación poética para «mover la voz a ti debida»: "Ed a te, Apollo, ancor noia non sia / Piaccar la luce tua lucida e bella / sotto il volto leggiadro di Maria / che bien da l'alta stirpe Pigmentella / Che

107. Cesare Corsi, «Musica reale e immaginaria...», p. 15. 
in più degno soggetto non poria / farsi celar; chè, se ben guardi, quella / splende...". El poeta interpela a los dioses de la entrada para continuar la laudatio de las hijas mayores de don Pedro, muy lejos aún de su destino como duquesa de Castrovillari, Isabel, y de Florencia, Leonor:

Poscia rivolto a Pallade e a Diana
Dissi: Non vi trovate altro ricetto
Che la beltà divina e non umana
Raccolta nel bel volto e casto petto
Di queste due, da cui or s'allontana
Ogni vano desire, ogni difetto [...]
Cosi dissio; onde colei che onora
Ogni leggiadra ninfa cacciatrice
Si celi ne le membra d'Eleonora,
E la saggia Minerva nel felice
Bel volto d'Isabella, in cui ogniora
forisce di beltà l'alma radice,
E con lor si staran sempre, qual credo,
Per onorar la stirpe di Toledo.

Se trataba, en último extremo, de expresar una armonía social y política que, desde las virtudes femeninas, se extendería a la alegoría musical, representada por la sirena Parténope con la lira que -en sus propias cuerdas, posible remedo de los seggi de la ciudad-invitaba a alejar toda disonancia ${ }^{108}$.

Finalmente, la armonía perseguida por la música y los versos desembocaría en nuevos conflictos. De momento, entre justas y banquetes, devaneos de celos y comedias arcádicas, la estancia del Emperador en Nápoles se demoró más de lo previsto. Las causas de esa demora fueron tanto políticas - por la reunión del parlamento del reino, las tensiones desatadas por el gobierno de Pedro de Toledo y las negociaciones diplomáticas- como financieras -debido a la costosa reunión del dinero necesario para pagar los gastos de la corte- ${ }^{109}$ y ceremoniales, por la sucesión ininterrumpida de festejos con que el virrey y la aristocracia intentaban retener a la corte para reforzar sus respectivas posiciones en la lucha por el poder. Pero las noticias del avance francés en el norte de Italia hicieron que predominara de nuevo el carácter de plaza militar en la patria de la sirena. El 27 de febrero el conde Maffei escribía al duque de Mantua que "vostra Eccellentia non se maravigliarà se più non haverà lettere de spassi et livree,

108. Véase Dinco Fabris, Partenope da sirena a regina. Il mito musicale di Napoli, Barletta, Cafagna, 2016.

109. El 7 de enero de 1536 el conde Maffei informaba desde Nápoles al duque de Mantua cómo el príncipe de Melfi, Andrea Doria, «m'ha detto che l'Imperatore non si puo partire di quea fin agli $x$ del mese che uiene, perche ancor che di Spagna gli siano uenuti cinquanta m. scudi peró á douer pagare tutta la Corte alcune Compagnie de Fanti et due di huomini d'arme, che uol menar seco a Roma ui bsognano oltra altre spese che accadera fare de gli altri denari, et che per tal effetto S.Mt. fa far adesso pratica con alcuni Mercadanti Genoesi per cauar cento $M$. scudi in prestito et che ancora non ui é resolutione alcuna de essi Genoesi, ma che pero spera in breue de redurgli a compiacere S.Mt. et se ben le paghe se finiscono presto, che peró ne vole anche del tempo», ASMa., Archivio Gonzaga, busta 812 , f. 30 . 
perché la materia de piaceri e voltata in arme, et ogniuno attende a poneri in ordine per questa guerra» ${ }^{110}$. El camino hacia Roma estuvo plagado de nuevas polémicas y vacilaciones sobre la conveniencia y la índole del recibimiento y las ceremonias que debían tributarse al César en la ciudad que, nueve años antes, padeciera el saqueo de sus tropas. Desde el primer viaje imperial a Italia, en 1529, la visita a la Urbe, reclamada por el Gran Canciller Gattinara, había sido pospuesta por la proximidad de aquellos hechos, hasta el punto de celebrarse la coronación por el papa en Bolonia. Ahora el triunfo sobre los infieles permitía abrigar nuevos proyectos sobre la tan deseada entrada en la Ciudad Eterna. En los meses en que la corte imperial permaneció en Nápoles el sueño de Roma movilizó a cortesanos, artistas y poetas, en permanente contacto con los activos círculos intelectuales y políticos - plagados a su vez tanto de napolitanos como de españoles- que gravitaban en torno al papa Pablo III Farnese. En principio no se desechaba ninguna idea, incluso la de una segunda coronación por el pontífice en la capital de los césares, hasta el punto de que el 7 de enero de 1536 el mantuano conde Maffei informaba que el Emperador había hecho traer desde España el manto para la ceremonia ${ }^{111}$. Cuando, finalmente, Carlos V hizo su entrada triunfal en Roma, la Urbe empezaba a recuperarse de los efectos del Saco mediante un gran programa de reconciliación pontificioimperial que tendría su eje en las obras de acondicionamiento y decoración efectuadas en el foro y el Vaticano. Uno de los muchos artistas súbditos del Emperador que entonces residían en Roma, el holandés Martin van Heemskerck, dejaría constancia de aquellos momentos en varios dibujos que, como otros cuadros y poemas coetáneos, aunaban el culto a la Antigüedad a través de las ruinas con la celebración de la campaña de Túnez. Diseñado por el humanista Latino Giovenale, el Triunfo romano fue obra de artistas italianos como Baldasarre Peruzzi, Antonio de Sangallo el Joven y Francesco Salviati, junto a otros procedentes de los Países Bajos, como Hermann «Posthumus». La imagen de la armonía volvía así a manifestarse.

En los años siguientes el César realizaría otras muchas entradas, como la de Milán en $1541^{112}$ o la que, un año antes, le llevó a la corte rival de París. Entre noviembre de 1539 y enero de 1540 Carlos, acompañado del duque de Alba, el conde de Egmont y otros nobles españoles y flamencos, atravesó Francia para dirigirse a Gante desde Espańa. Aquel viaje magnífico permitió el encuentro de las cortes imperial y francesa, dejando una fuente impronta en la

110. ASMan, Archivio Gonzaga, busta 812, f. 224r., cit. por Diane Bodart, Tiziano e Federico II Gonzaga..., p. 140, nota 453.

111. Andrea Doria le había informado de que «S.Mt. s'ha fatto condurre di Spagna il manto per fare la incoronatione in Roma, ma non quello che hauea in Bologna, perche essendo una parte delle zoie che ui erano sopra della Imperatrice, lo fece sfornire, et diede una gran parte d'esse alla pta. Imperatrice, et doppo ne fece fare unaltro qual ancor che non fosse si ricco como era quello, che peró era anche qto. bello et ricco», Niccolo Maffei al duque de Mantua, Nápoles, 7 de enero de 1536, ASMa., Archivio Gonzaga, busta 812, f. 30.

112. Véase Silvio Leydi, Sub umbra imperialis Aquilae. Immagini del potere e consenso politico nella Milano di Carlo V, Florencia, Olschki, 1999. 
tradición literaria ${ }^{113}$. Atrás quedaba la corte galante de los meses napolitanos, aunque su recuerdo seguiría vivo hasta el final del período virreinal, mientras el género arcádico se proyectaba en fuentes, poemas y obras teatrales. La difícil coyuntura política de la visita de Carlos V quedaría relegada por su esplendor en el recuerdo posterior, como reflejaría la siguiente y última estancia de un soberano español: la de Felipe V en 1702. Como Carlos V, cuyo recuerdo surgió inevitablemente en los preparativos del nuevo recibimiento, el primer Borbón entró por Porta Capuana acompañado por un larguísimo cortejo hasta la catedral, donde juró las leyes y privilegios del reino, para dirigirse a Castel Nuovo, cuyas llaves le entregó su castellano, antes de recluirse en el palacio real. En conjunto, se siguieron los mismos criterios organizativos y ceremoniales que en la entrada imperial, como testimonio de la permanencia de un ritual fundado en la sacralización del poder que pretendía expresar la identidad histórica y jurídica del orden social y político ${ }^{114}$. Al igual sucedió con las celebraciones que - pese a algunos episodios de descontento- sellaron la lealtad de la nobleza con el ejercicio liberal del favor regio durante las semanas siguientes, a través de unas formas de sociabilidad aristocrática consolidadas en torno al ritual del banquete y los juegos caballerescos. Como bajo Carlos V, los cronistas insistieron en la destreza ecuestre del monarca y en su galantería. Pero ni las justas, ya mero espectáculo sin alma, ni el banquete, encerrado en rígidas normas de etiqueta, serían ya la expresión de la corte galante que, surcada por ambiciones feudales y políticas, conocieron Garcilaso y Pedro de Toledo.

113. Véase l'ordre tenu et gardé a l'entrée de treshault et trespuissant prince Charles empereur tousjours auguste en la ville de Paris, Gilles Corrozet y Jean du Pré, 1539 [1540]. Cf. Augustin Redondo, "Un témoignage espagnol sur la cour de France en 1539", Mélanges de la Casa de Velázquez, vol. II, no 1, 1966, pp. 333-337 y Verdun Louis Saulnier, «Charles V traversant la France: ce qu'en dirent les poètes français», en Jean Jacquot (ed.), Les fêtes de la Renaissance, París, Centre National de la Recherche Scientifique, 1975, pp. 207-233. El viaje sería evocado por Lope de Vega en su comedia Carlos Ven Francia, compuesta en 1604. Véase Araceli GuillaumeAlonso, "Historicité et dramaturgie dans Carlos V en Francia», en Charles Quint et la monarchie universelle, París, Presses de l'Université de Paris-Sorbonne, 2001, pp. 127-144 y Luc Capique Schneider, Estudio introductorio y edición critica con notas de Carlos V en Francia de Lope de Vega, tesis doctoral, Universidad de Navarra-Université de Pau, 2014.

114. Véase Giuseppe Galasso, Napoli spagnola dopo Masaniello, Nápoles, Sansoni Editore, 1982, vol. II, pp. 634-650 y Riccardo Lattuada, «Ricostruzione del viaggio a Napoli di Filippo V di Spagna, con una lettura nuova del monumento equestre di Lorenzo Vaccaro», en Vega De Martini (ed.), Il mestiere delle armi e della diplomazia, Nápoles, Edizioni Scientifiche Italiane, 2013, pp. 114-125. 
